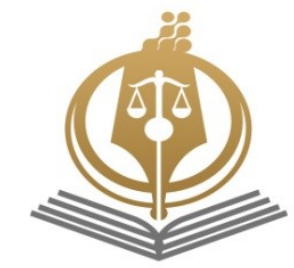

Interdisciplinary Legal Research

Jul 2020, 1(2): 66-85

Available online on: www. ilrjournal.ir

e-ISSN: 2717-1795

ORIGINAL RESEARCH PAPER

\title{
Legal Nature and Basis of Protecting "Knowhow"
}

Majid Sarbazian $^{1 *}$

\section{Received: \\ 23 May 2020 \\ Revised: \\ 11 Jun 2020 \\ Accepted: \\ 22 Jun 2020 \\ Available Online: \\ 01 Jul 2020}

Keywords:

Knowhow,

Property,

Ownership,

Contract.

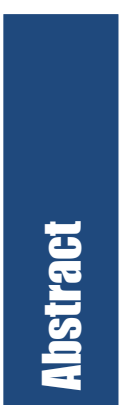

Background and Aim: "Knowhow" is a term that is less considered as the main subject of the contract. It is aimed at this article to explain the meaning and characteristics of this notion.

Materials and Methods: This is a descriptive Study.

Ethical Considerations: Honesty and confidentiality have been observed.

Findings: In general, "Knowhow" is a form of knowledge; it contains non material goods; it cannot be registered; it possesses confidentiality; it is identifiable; it is transferable and has business value.

Conclusion: "Knowhow" is a kind of property and therefore one can own it; but it is not goods in action (Ein). The methods of protecting "Knowhow" are due to Tort and contractual responsibility.

1* Assistant Professor, Department of Private Law, Faculty of Law, Shiraz University, Shiraz, Iran.

Email: Sarbazian20@gmail.com Phone:+989170616239

Please Cite This Article As: Sarbazian, M (2020). "Legal Nature and Basis of Protecting "Knowhow". Interdisciplinary Legal Research, 1 (2): 66-85. 
مقاله يزوهشى

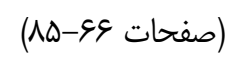

\section{ماهيت و مبانى حقوقى حمايت از دانش فنى \\ مجيد سربازيان'}

Email: Sarbazian20@gmail.com استاديار، گروه حقوق خصوصى، دانشكده حقوق، دانشكاه شيراز، شيراز، ايران.

$$
\text { دريافت: }
$$

زمينه و هدف: "دانش فنى" اصطلاحى است كه كمتر به عنوان موضوع اصلى قرارداد مورد توجه واقع شده است فلذا تبيين مفهوم و ويثگى هاى آن هدف اين يزوهش است. مواد و روشها: اين مقاله به صورت توصيفى - تحليلى نكاشته شده است. ملاحظات اخلاقى: در اين تحقيق، اصالت متون، صداقت و امانتدارى رعايت شده است.

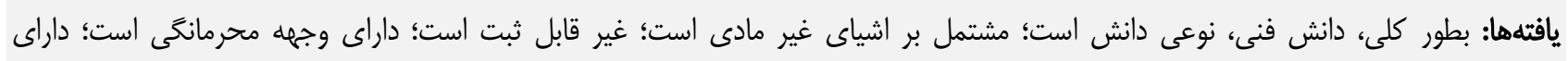

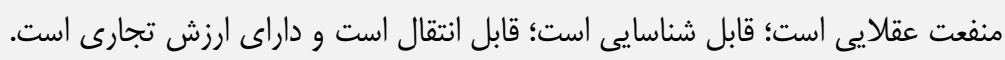

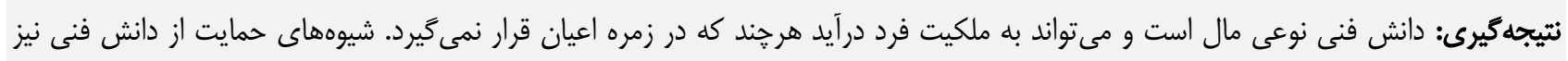
مى تواند از طريق مسؤوليت مدنى و مسؤوليت قراردادى باشئ داثل كلمات كليدى: دانش فنى، مال، ملكيت، قرارداد. 
باشد، بهتر است براى شناخت دانش فنى، ويزگگ هاى آن بيان

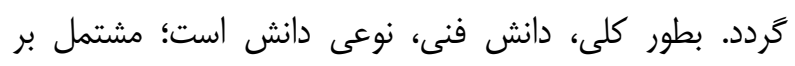

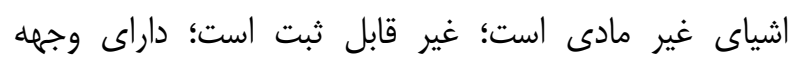
محرمانگى است؛ داراى منفعت عقلايى است؛ قابل شناسايى

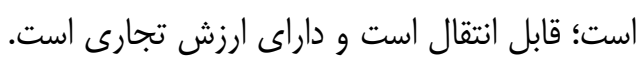

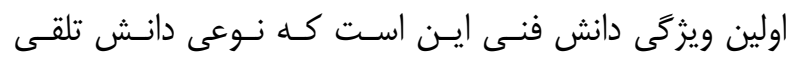

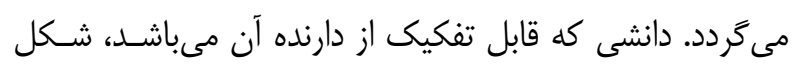

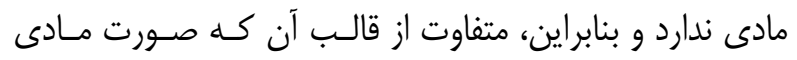

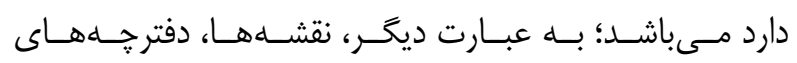

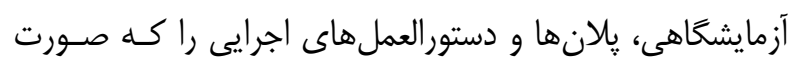

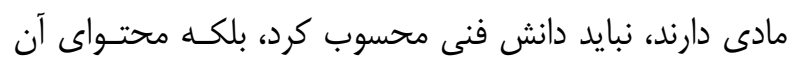
يعنى اطلاعات مربوطه است كه دانش فنى محسوب مى دارود.

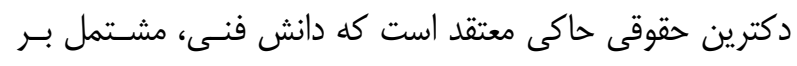

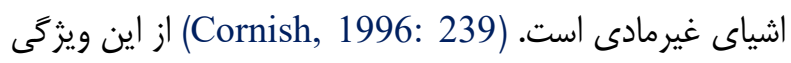

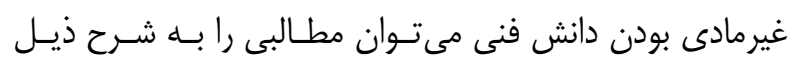

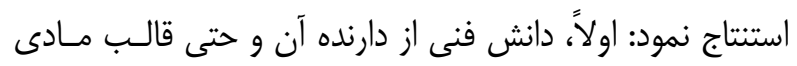

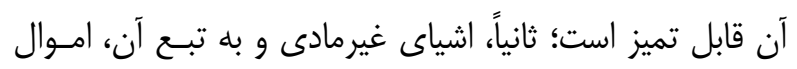

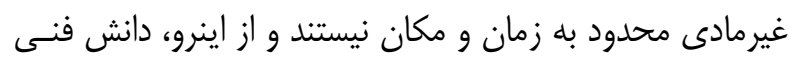

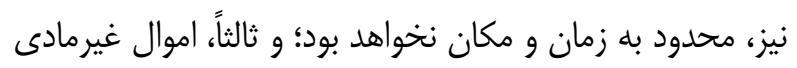

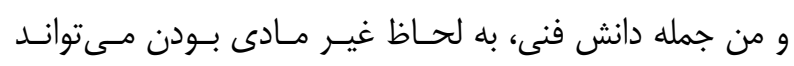
موضوع كاركردهاى متفاوت و متنوعى قرار گيرند.

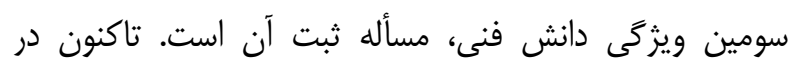

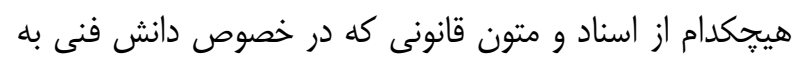
تصويب رسيده، شرط قابليت ثبت براى دانش فنى لحاظ نخرديده و مطابق متون قانونى و رويههاى قضايى، لازم نيست

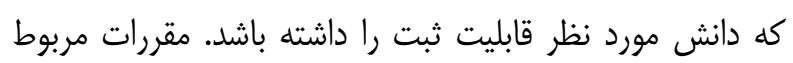

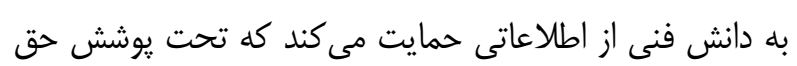

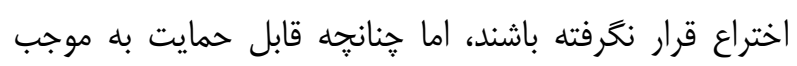
حقوق مالكيتهاى فكرى باشد اما هنوز به ثبت نرسيده باشد، حمايت از آن در قالب دانش فنى بلامانع مىباشد.

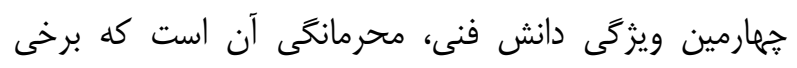
ترجيح مى دهند از آن به جديد بودن دانش فنى تعبير كنند. (Chavanne, 1998: 535)
مقدمه 1- بيان موضوع: 》دانش فنى" اصطلاحى است كه گر جه

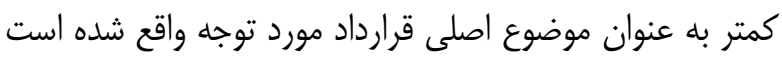
اما در اكثر قريب به اتفاق قراردادهاى ليسانس به جشهم مىخورد. همين امر باعث شده كه محققان به تبيين مفهوم و

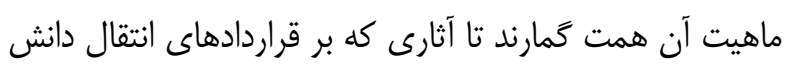

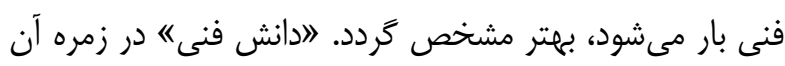

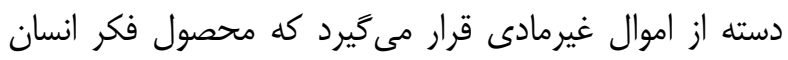
است و از جمله اهداف عمده حمايت از محصولات فكرى اين

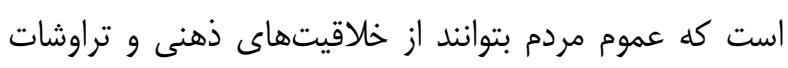

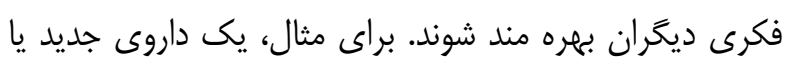

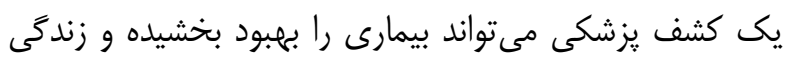
را طولانىتر سازد؛ ريزيردازندههاى رايانهاى مىتوانند كارآيى بيى بئي

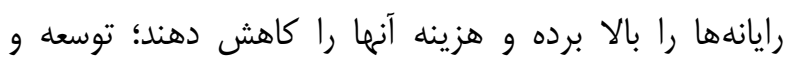

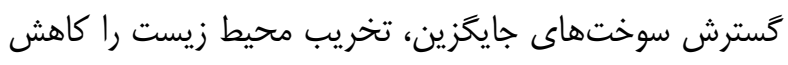

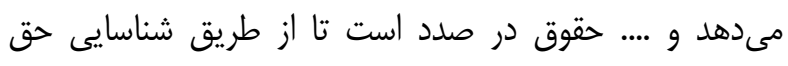

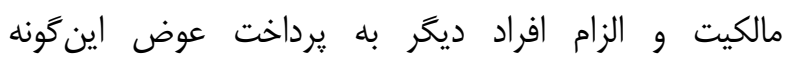
تلاشهاى فكرى، به تحقق آنها كمى كند. عوض معنوى اين

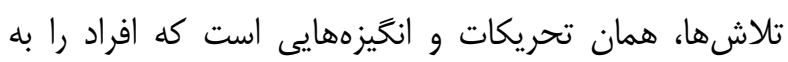

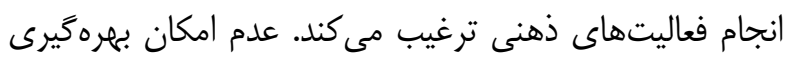

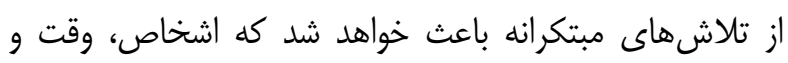
هزينهاى را صرف اين مهم نكنند. در نظام حقوقى ايران، ماهيت اين موضوع به درستى تبيين نشده است. از اينرو در اين يزوهش تلاش مائ مىشود ماهيت ماهيت و

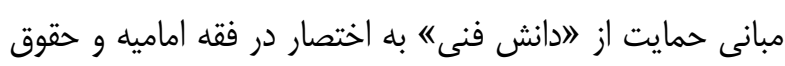

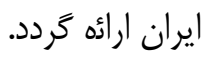

r- تبيين مفاهيه: اصطلاح دانش فنى در سيستمهاى حقوقى تحت عناوين متفاوتى از قبيل 》اطلاعات محرمانه《، \اسرار

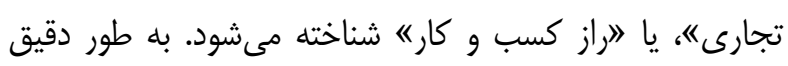
نمىتوان ميان اين مفاهيم تمايز ايجاد كرد و در اكثر موارد اينها

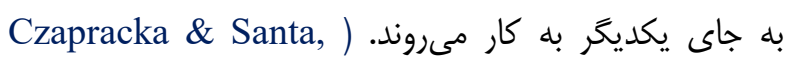
2008:230 از آنجايى كه هر تعريفى نمىتواند جامع و مانع 
وجود نخواهد داشت. البته اين امر باعث نمىشود كه شرط مربوط به توصيف و شناسايى منتفى شود بلكه لازم است تا اين توصيف به صورت كلى صورت گيرد و به هيج وجه بحث مله قابليت شناسايى نفى نمى شود.

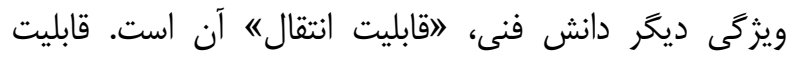

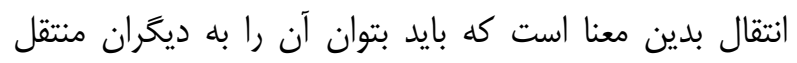

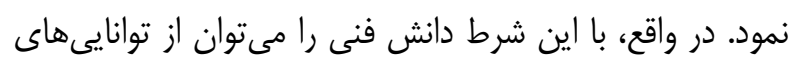
شخصى كه امكان انتقال آن به ديخران وجود ندارد، تميز داد. مهارت فنى و تخصص و تجربهاى كه قابل تفكيك از دارنده آن نباشد، دانش فنى محسوب نمى شود. معيار تميز ميان تجربه نهريه شخصى كه ذاتى فرد است و دانش فنى كه متعلق به بنگاه يا

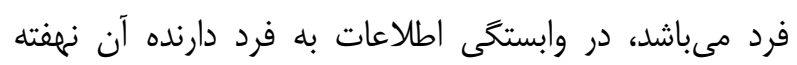

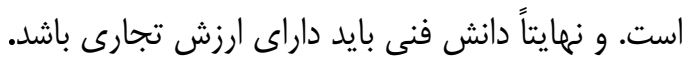

ץ- روش تحقيق: روش تحقيق، به صورت توصيفى - تحليلى است.

\section{بحث و نظر}

در اين بخش به تبيين ماهيت حقوقى دانشفنى يرداخته خواهد

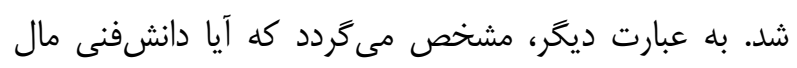

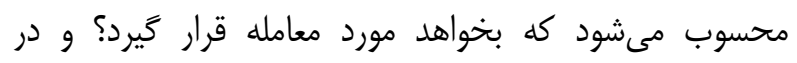

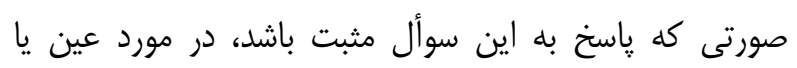

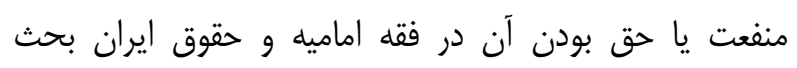
خواهد شد.

\section{1- ماهيت حقوقى دانش فنى}

در حقوق ايران، اموال را از جهتى، به مادى و غيرمادىى، و از جهت ديگر، به عين، منفعت و حق تقسيم مى كنند. در اين قسمت، دانش فنى از منظر فقه اماميه و حقوق ايران مورد بررسى قرار مى كيرد.

1-1- فقله اماميه

براى آنكه بتوان ماهيت دانش فنى را از منظر فقه اماميه بررسى

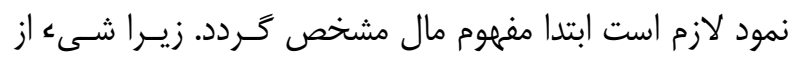

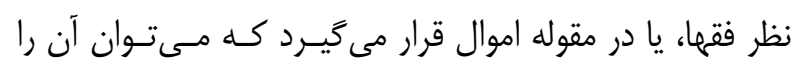

كه در اينجا از آن صحبت به ميان آورده مىشود جديد بودن نسبى است. دانش فنى ممكن است براى عده زيادى شناخته

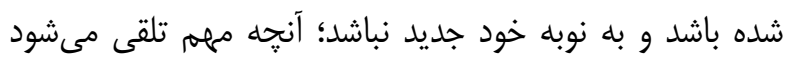
اينست كه عموم به آن دسترسى نداشته باشند. در حقيقت، اعتبار دانش فنى به ارزش اقتصادى آنست؛ ارزش اقتصادى

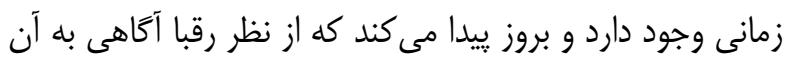
اطلاعات باعث صرفه جويى و در نتيجه توجيه يرداخت يول در درد ازاى به دست آوردن آن بشود. بنابراين، اخر موضوع قرارداد دانش فنى براى عده زيادى شناخته شده باشد و بسيارى از باز صنعتخران در آن شاخه صنعتى بدان دسترسى داشته باشند در حدودى معتبر است كه اطلاعات مربوطه براى ذينفع آن قرارداد، كارآيى داشته و مفيد باشد. ( Chavanne, 1998

ينجمين ويثگى دانش فنى "اساسى يا ضرورى بودن آن"' است. ويزگى مزبور، مشخص مى كند كه دانش فنى، برى براى

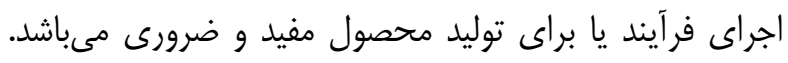

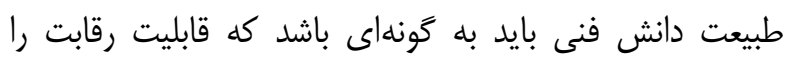

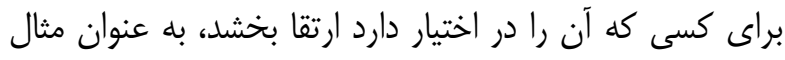

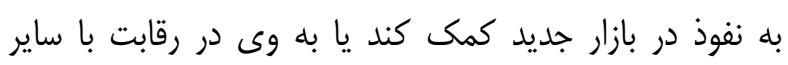

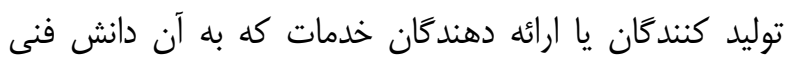
خاص يا دانش فنى مشابه ديخرى دسترسى نداشتهاند امتيازى دئ دان اعطا نمايد. ويثزى بعدى، قابل شناسايى بودن دانش فنى است. منظور از

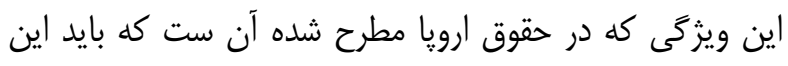

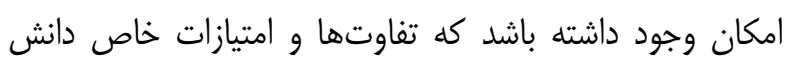

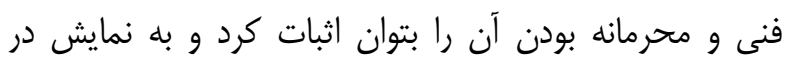

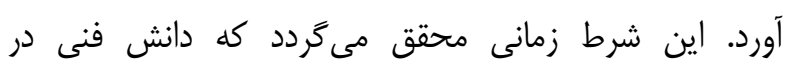
دستورالعمل هاى كتبى يا هر سند نوشته ديخرى بروز ييدا كند.

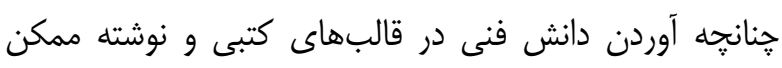

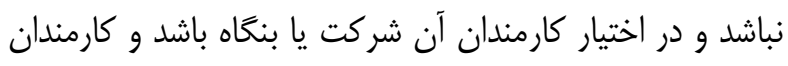

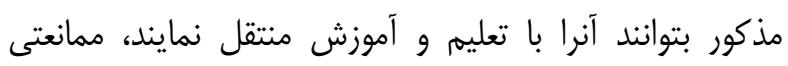

\footnotetext{
${ }^{1}$ - Substantiality
} 
آن و اين كه مىتوان آن را در زمره دارايىها قلمداد نمود، ترديد

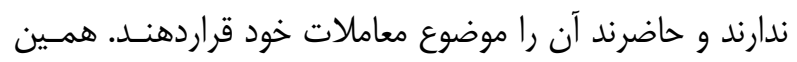
كه افراد معينى در جامعه به ارزشمند بودن دانش فنس فنى اذعـان دارند و حاضرند براى بدست آوردن آن يول صرف كنند، نشـان آنسان

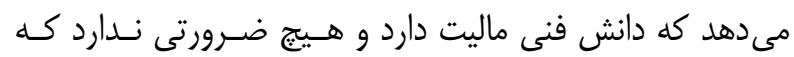

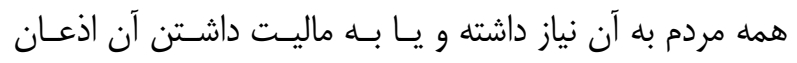
كنند. بنابراين، از نظر لغوى هيج ترديدى وجود ندار ندارد كه دانش فنى مال محسوب مىشود و نمىتوان كفت كه عنوان ماليت از

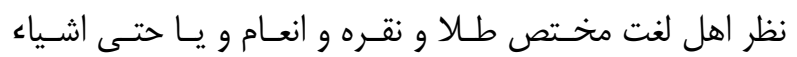

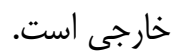
|-1-1-Y- از منظر فقها: فقها در مباحث مختلف بـهـ بيـان و

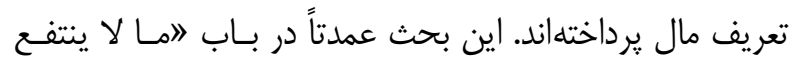

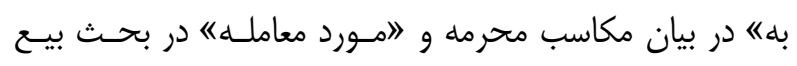
مطرح شده است. اكثريت فقها مال را مفهومى اعتبارى مى دانند

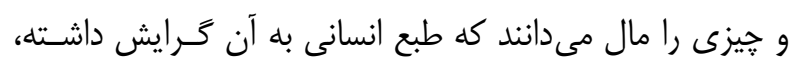

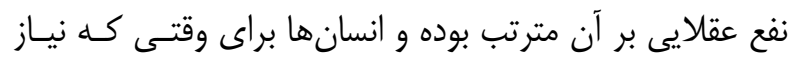
دارند، ذخيره مى كنند. (الجزيرى، هأ(ا: ه/عq) عبارات برخى از فقهاء صراحت دارد در اين كه مال به هر جيزى اطلاق مى شود

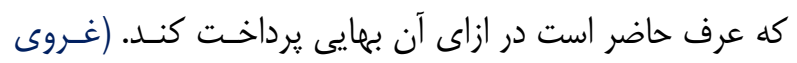

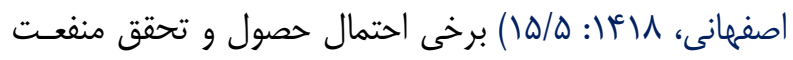

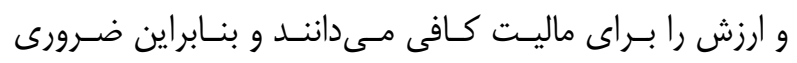

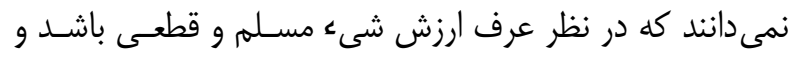

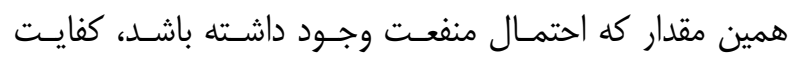
مى كند. اين مطلب عمدتاً در بحث عمل فرد آزاد (حر) بيان شده

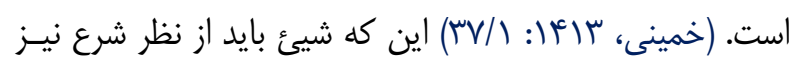
مباح باشد تا مال محسوب شود، مورد اختلاف است؛ البته مبـاح

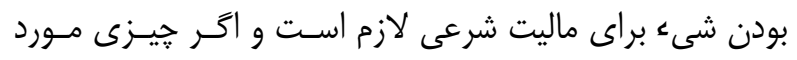

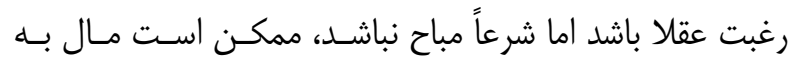

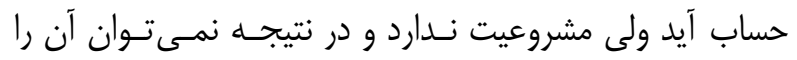

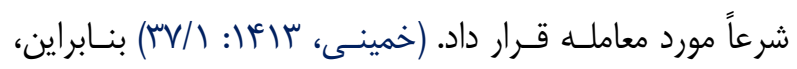
برخى ميان ماليت شرعى و عرفى قائل به تفكيك شدهاند، بدين

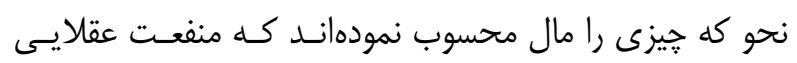

مورد معامله قرار داد يا اينكه مال محسوب نمىشود. همجنانكه

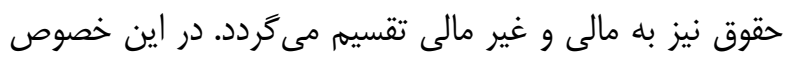

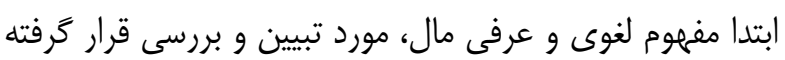

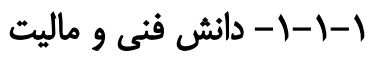

|-1-1-1-از منظر لغويون: به طور كلى، از تعـاريف لغويـون

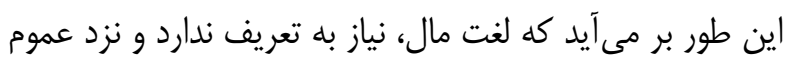

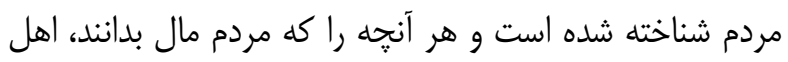

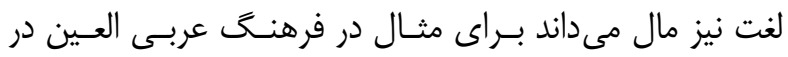

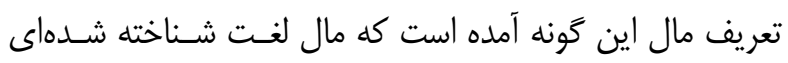
است و جمع آن اموال است. نكته مهم در تعريف لغويون آنست

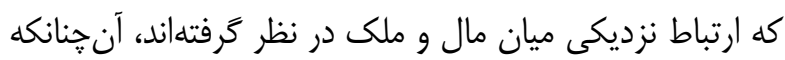
برخى در معناى مال كفتهاند كه مال در اصـل دارايسى از قبيـل

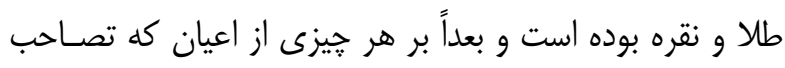

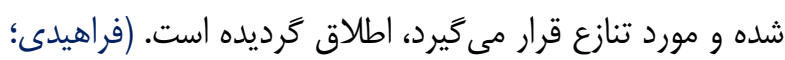

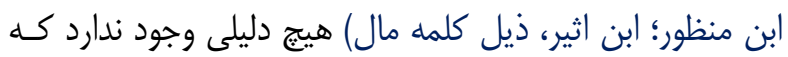
مال فقط به اعيان اطلاق شود، بلكه شامل منافع و اعمـال نيـز

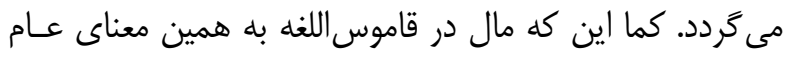

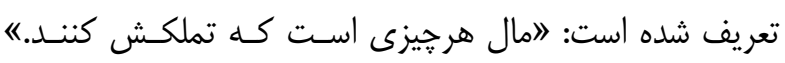

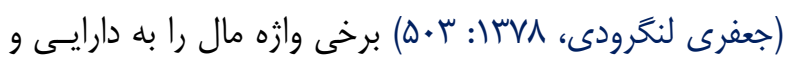
آنجه كه در ملك شخص باشد اطلاق كـردهانـــ. (عميـد، ذيـل

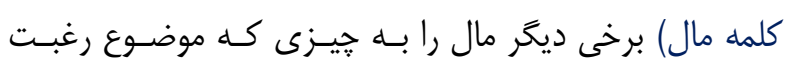

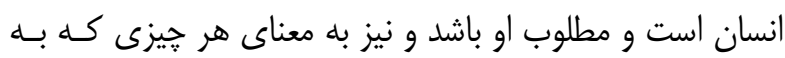

تملك انسان در آيد، تعريف كردهاند. (دهخدا، ذيل كلمه مال)

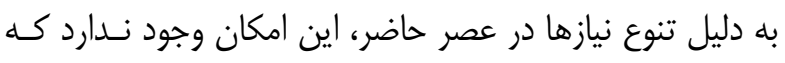

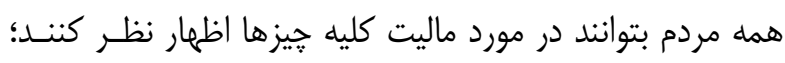

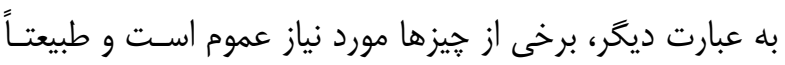
كليه مردم در خصوص ماليت آن اظهار نظر مى كنند. در مقابل، بسيارى از جيزهاى ديخر هرجند ارزشمند اسـت امـا مـورد نيـاز

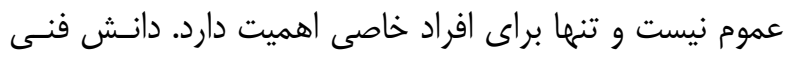

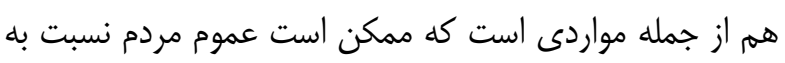

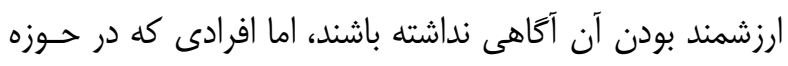

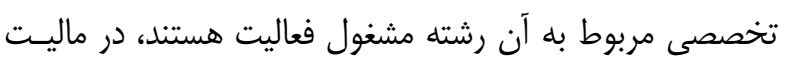


مال باشد، ...، حتى اگر در نزد عده معدود يا شخص خاصى مال

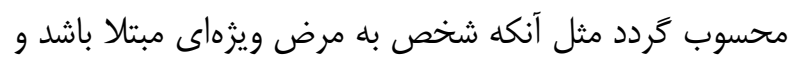
درمان وى در همان جيزى است كه ديخران رغبتى بدان نشـان

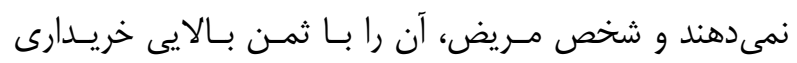

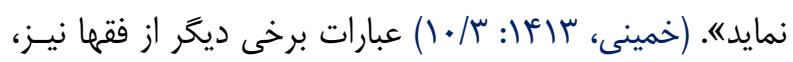

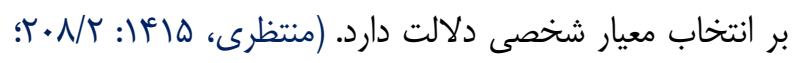

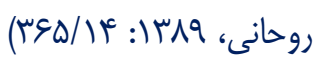
حتى در صورتى كه ملاك نوعى باشد، منظور قضاوت عرفى در

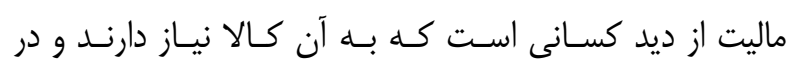
شرايطى هستند كه آن كالا مىتواند نيازهاى آنها را تأمين كند.

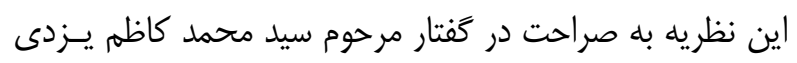
منعكس شده است: "اولو اين كه مورد معامله منفعت نادرى داشته و يا حتى مد نظر شخص خاصى قرار كرفته باشد... و اين ايراد كـه فئ.

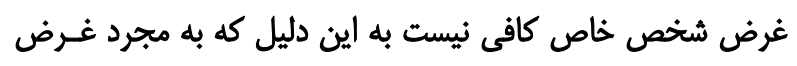

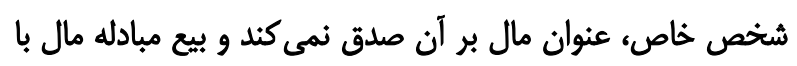

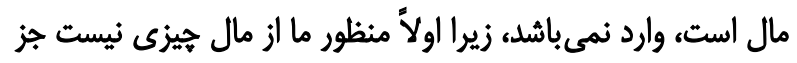
سلطنت شخص بر عين آنجنان كه ديكرى نتواند به آن دست يابد... و ثالثاً اين كه غرض شخصى هم به غرض نوعى برمى بردد زيرا هر انهان كس ديكرى هم كه در مقام و موقعيت وى قرار كيرد، آن شئ مورد

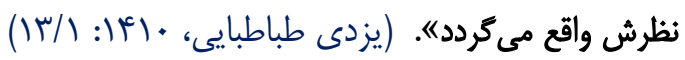

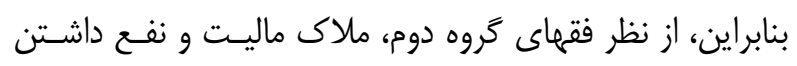
شى، شخص است اما نه هر شخصى بلكه شخصى كه از عقل

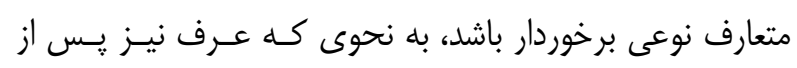

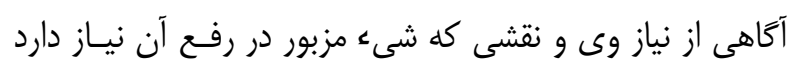
به ماليت آن اذعان مى كند. بسيارى از اشياء امــــزوه مـورد نيـاز

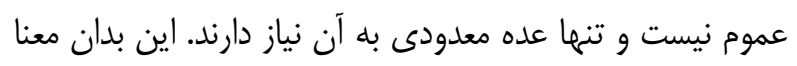
نيست كه اينها ماليت ندارند. قطعات يدكى هواييمايى كـه تنهـا

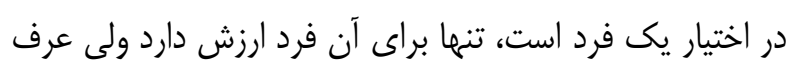

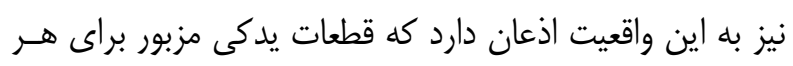
كس ديخرى نيز كه صاحب هواييما بود، ارزشمند تلقى مى شــد،

ولو در عمل تنها يك فرد صاحب جنين هواييمايى است.

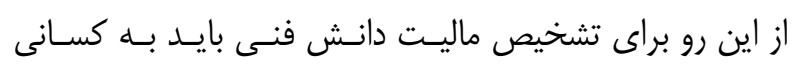
مراجعه كرد كه در آن صنعت و حرفه مشغول به كـار هستـند و
داشته باشد ولى براى ماليت شرعى قيد محلله را اضافه كردهاند.

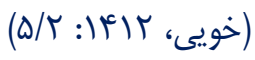
مشهور فقها، رقابت ميان مردم را نيز براى ماليت شرط مىدانند

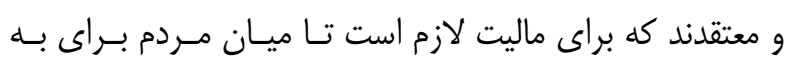
دست آوردن شىء مورد نظر، رقابت وجود داشـته و بــهـ عبـارت

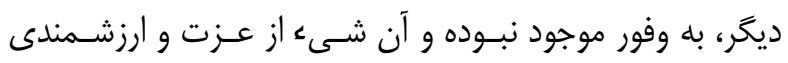

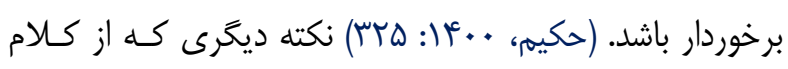

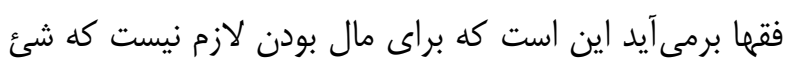

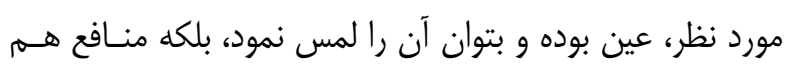

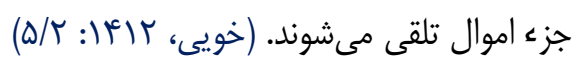
براساس مطالبى كه از متون فقهى كفته شد، جيزى مـال تلقسى

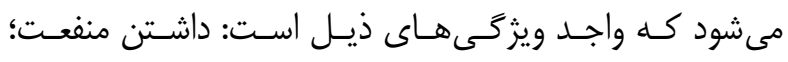

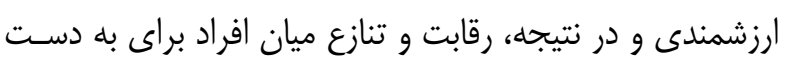

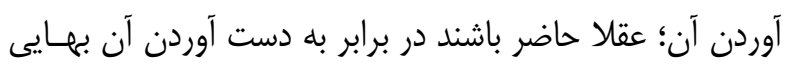

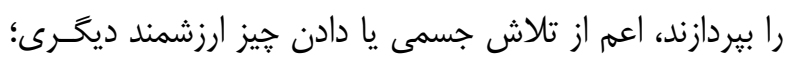

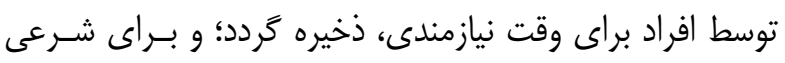
بودن لازم است كه مباح بوده و داراى منفعت محلله باشد. با توجه به مفهومى كه از دانش فنى در بخش اول مقالـه ارائهـ

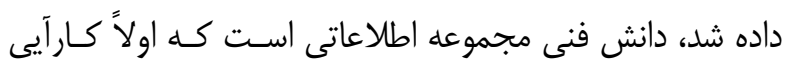

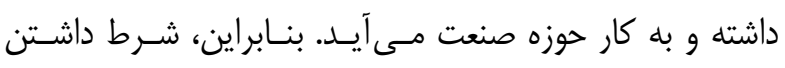

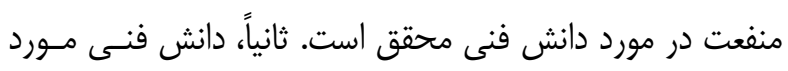

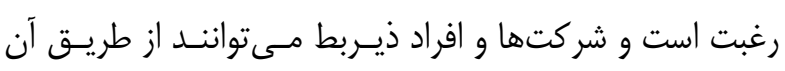

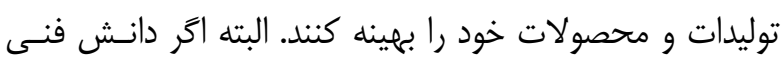

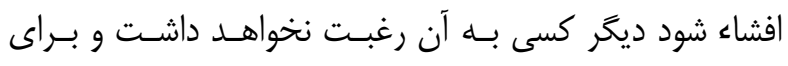

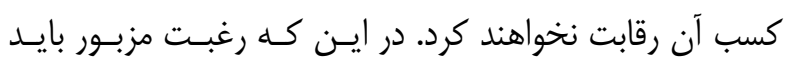

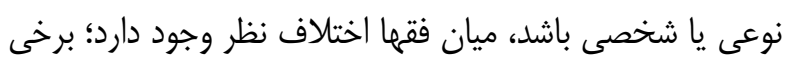
معتقدند كه عموم مردم بايد به آن رغبت داشته باشـند و تعبيـر

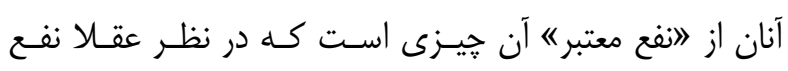

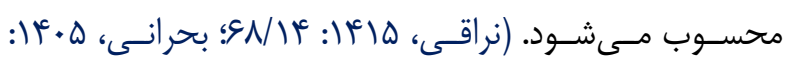

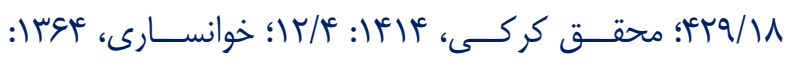
س/T/1) برخى ديخر از فقها ملاكى را شخصى مى دانند. به عنوان مثال كفتته شده است الازم نيست كه شى مورد مورد معاملـه نوعـاً 
ثانياً، خود فقها نيز معترفاند كه موقعيتهـاى مكـانى و زمـانى يك موضوع مى تواند در تعلق حكم بر آن نقش داشته باشـد. در بيشتر موارد دليل حكم حرمت و جواز در خريد و فـروش اشسيا،

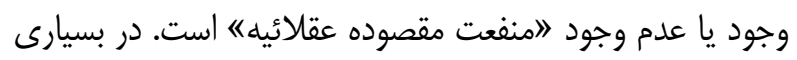
از موارد، وجود يا عدم وجود منفعت نمى توانـــ بـهـ طـور مطلـق مورد قضاوت قرار گيرد بلكه خه بسا جيزهايى كـه در زمـان يـاــا مكان خاصى داراى منفعت است و در زمان يـا مكـان ديخـــى مورى

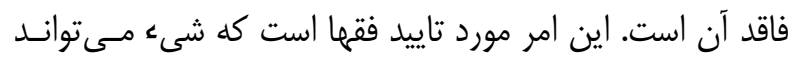

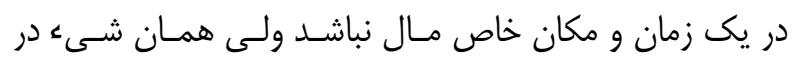

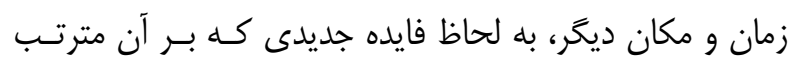

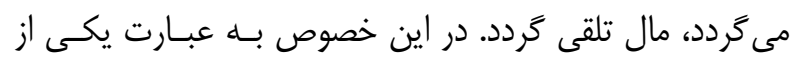

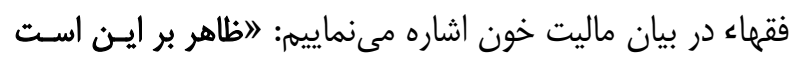

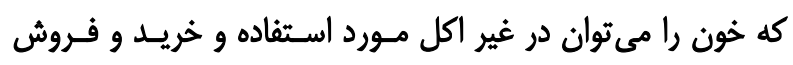

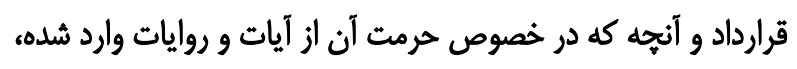

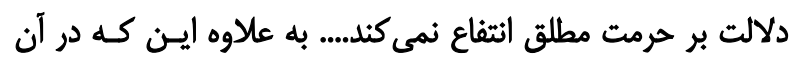

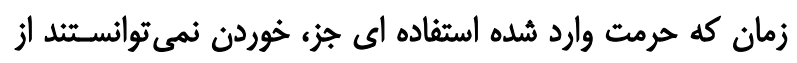

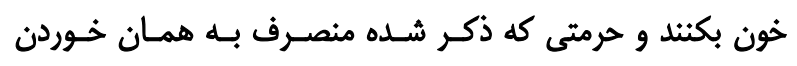

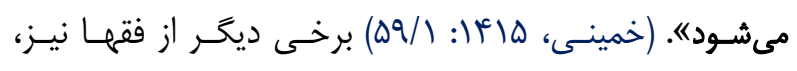
مضمون اين كلام را تاييد نمودهاند. (مرتضوى لنخرودى، بـى لـا:

نسبى بودن ماليت شىء به نوعى مى تواند در تأييـد مـال بـودن

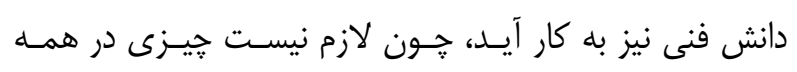

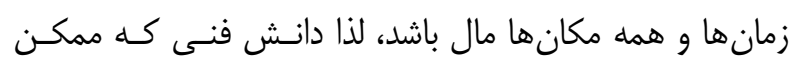

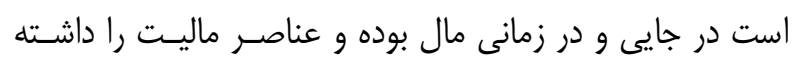

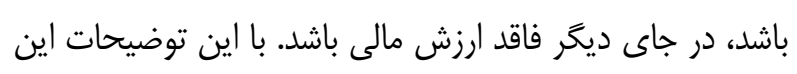
ايراد دفع مى شود كه ماليت دانش فنى محدود به زمان و مكان خاصى است و ممكن است با افشاى آن از ماليت بيفتد. از آنجا كه شارع در زمينه شناسايى مالكيت، سيره عقلا را امضـا كرده است، عدم وجود جننين سيرهاى در زمان شارع نسـبت بــهـ

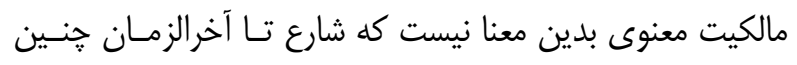

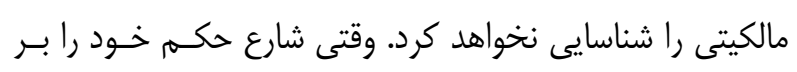

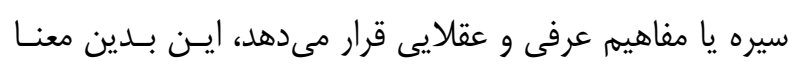
است كه بناى شارع امضاء همان نظمى است كه عقلاء در بـين

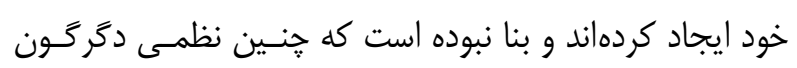

به ارزش آن اذعان دارند. دانش فنى توسط دارنده مورد حفاظت

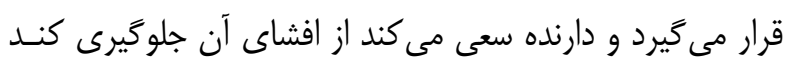

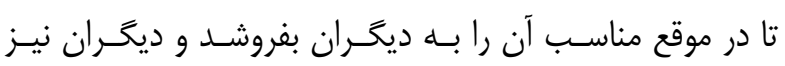

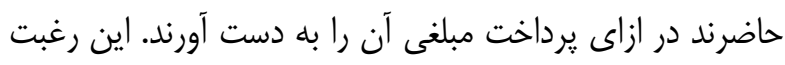
كافى است كه دانش فنى در زمره اموال قرار گيرد. 1-1-1- دانش فنى و قابليت تملك علاوه بر ايراد ماليت كه بر دانش فنس وارد شــــ اسـت، ايسراد ديخرى مطرح شده است كه دانش فنى قابليت تملك ندارد. اين

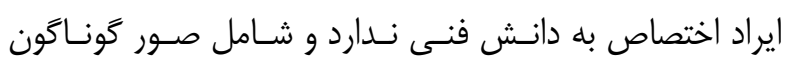

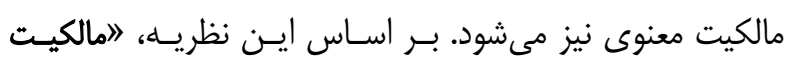

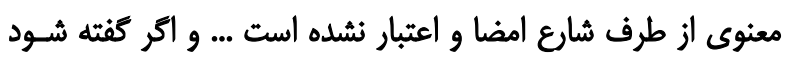

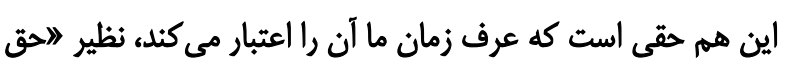

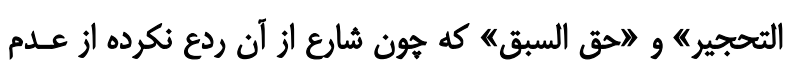
ردع او استكشاف امضا مىنماييم و معتبر است؛ جواب اين است كه اله نسبت به حقوقى كه در زمانهاى بعد از عصر شارع مقدس و ائمسه

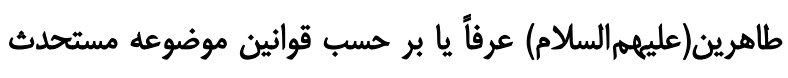

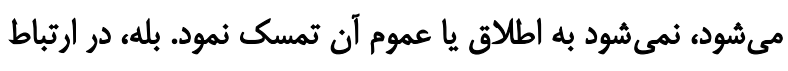

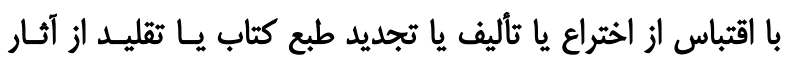

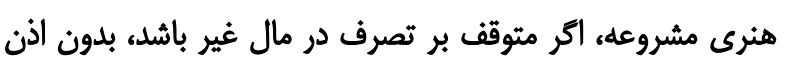

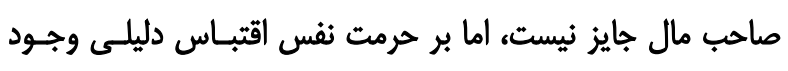

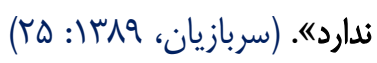

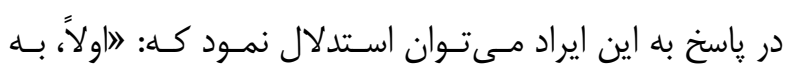

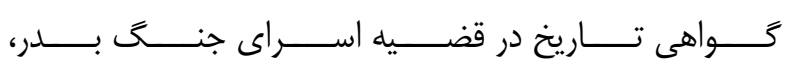

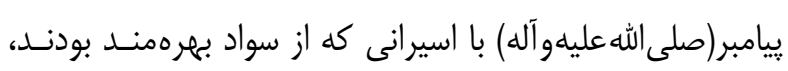

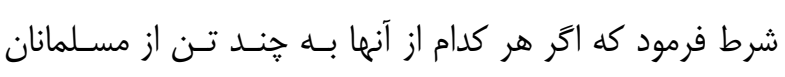

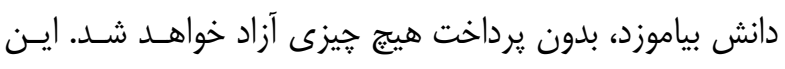

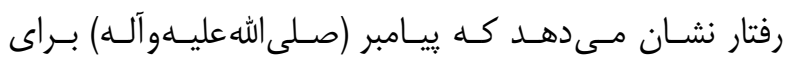
آموختههاى انسان ارزش مالى قائل بودند و آن را قابل مبادله با دهاب

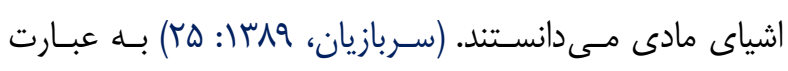
ديخر، آثار علمى نيز قابل تملك است و شايد بـهـ همـين دليـل برخى از علماى متقدم شيعه، مثل سيد مرتضى و شيخ طوسى، لمي،

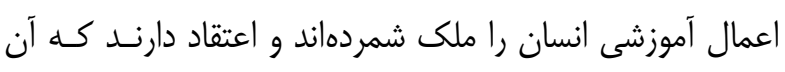

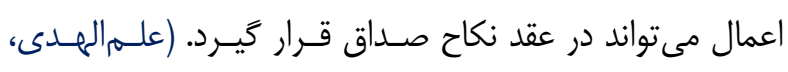

(rq): : I I 
الالمراد من العين ما إذا وجد فى الخارج كان جسما مشـتملا علي

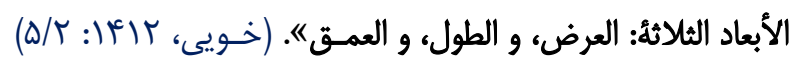

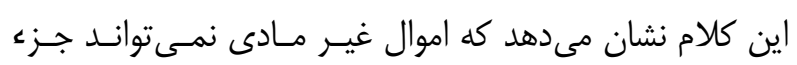

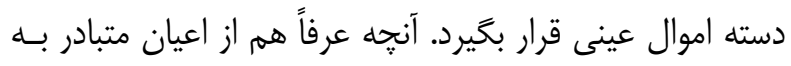
ذهن مىشود همان اشياى ملموس خارجى است. از طرف ديخر،

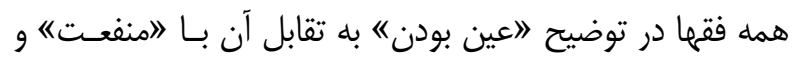

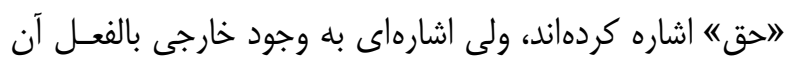

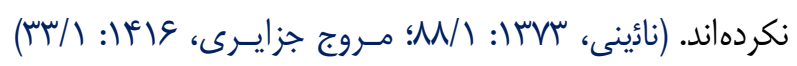

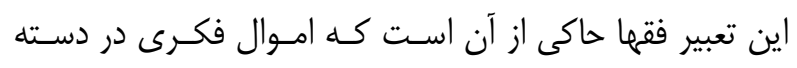

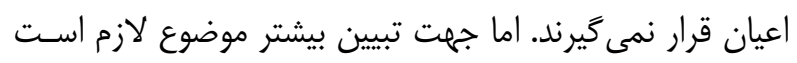
به بررسى مفهوم حق و منفعت بيردازيه.

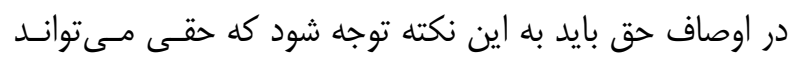
مال تلقى گردد كه قابل نقل و انتقال باشد. در تعريف اين نـوع إنها از حق كه بيشتر در مبحث موضوع عقد و در مبحث عين بودن

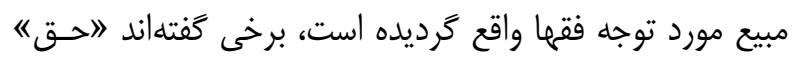
عبارت از نوعى سلطنت بر شىء مى باشد، نظير حق تحجير كـهـ

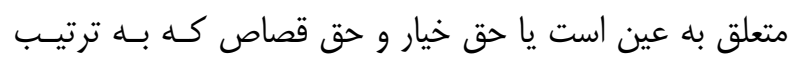

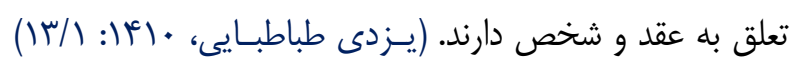

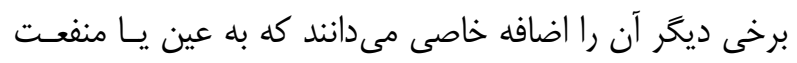
تعلق مى گيرد عدهاى ديخر با تاييد مطلب اخير آن را از سلطنت

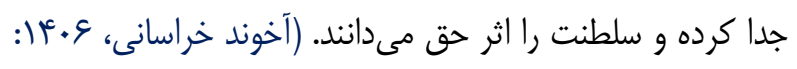
ه) در همين جا بهتر است به عبارت يكى از فقها در مقام تمـايز

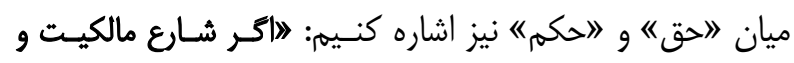

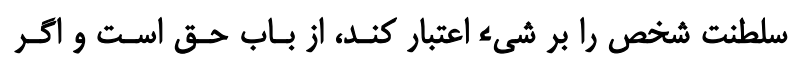

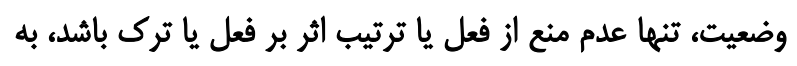

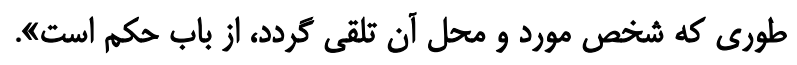

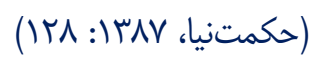

در يك جمع بندى كلى از كلام فقها، حق را مىتوان عبارت از

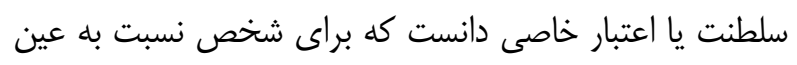
يا منفعت وجود دارد. با توجه به تعريف فوق از حق، آيا مىتوان

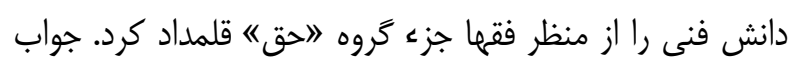

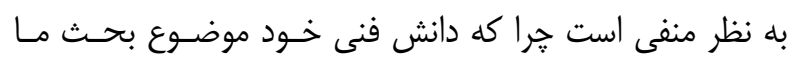

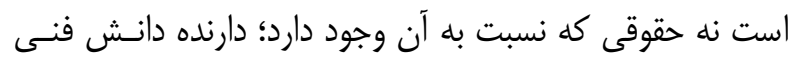

شود. اين امر خود به جاودانه بودن احكام شرع دلالـت دارد كـهـ خود را با مقتضاى زمان تطبيق مىدهد.

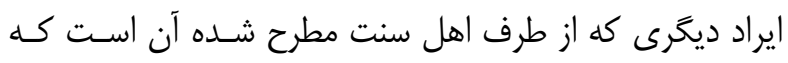
امالكيت معنوى با رسالت و قداست علم از نظر اسلام ناساز كار است و معتبر دانستن اين حق سبب حصر و حبس آثار علمى و و و كتمان علم مى گردد كه مورد نهـى قـر آن كـريم قـرار كرفتـه:

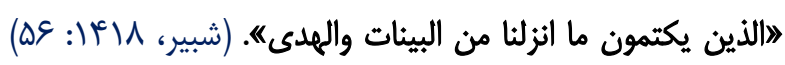
در جواب اين استدلال بايد كَت مسلماً شكى نيست كه اسـلام

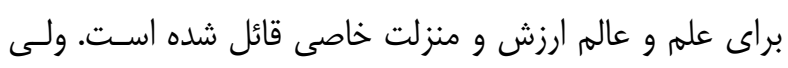

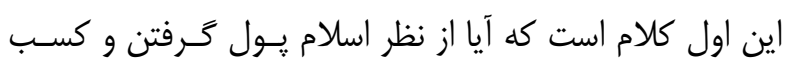

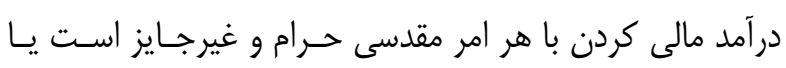

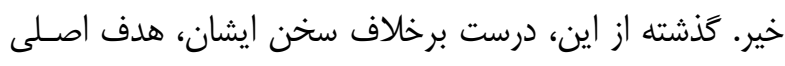

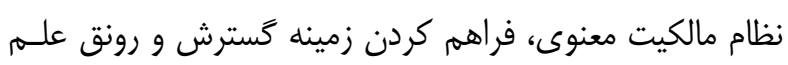

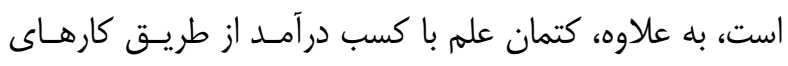
علمى، دو جيز كاملاً متفاوت است.

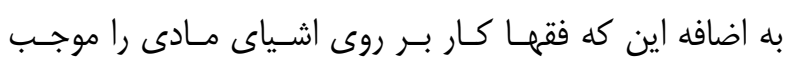
ملكيت مى دانند، مثل اين كه سنَ مباحى را به ابزارى تبـديل كنيه كه قيمت داشته باشد. حال اخر كسى كتابى را تأليف كند،

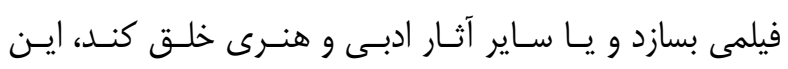
استدلال نمى تواند درست باشد كه هون اين آثار مـادى نيسـتـنـ

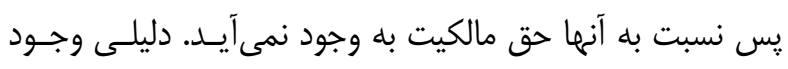
ندارد كه كار روى اشياء مادى موجب مالكيـت شـود ولى كلى كار

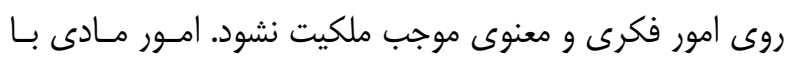

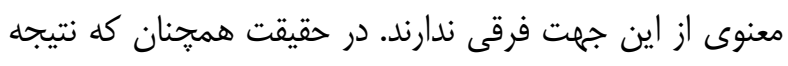
كار بر روى اشياى مادى حائز اهميت بوده و از احترام برخهوردار است بايد نتيجـهـ كـارى كـه روى امـور غيــر مـادى نيـز مـال محسوب گردد، زيــرا در ايـن خصـوص ردعـى از سـوى شـارع صورت نخرفته است. |-1-r- دانش فنى و مفاهيم حق و منفعت: فقهـا در مبحـث

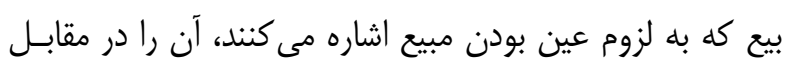

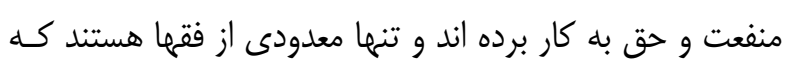
تعريف مختصرى از آن ارائه نموده و اين گَونه عنوان كرده انـد: 
مىتواند به اين دليل باشد كه قبلاً اموال غيرمادى، رواج فعلى

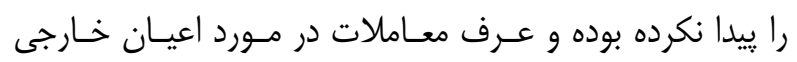
صورت مى مرفته است. ا-r- حقوق موضوعه ايران در قانون مدنى و ساير قوانين ايران عبارت لامال ه تعريف نشده

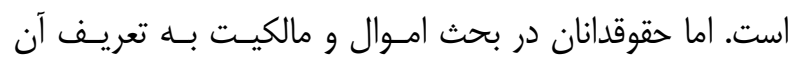

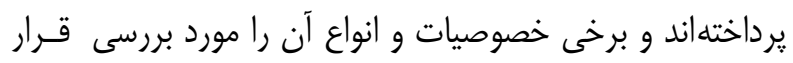
دادهاند. يكى از حقوقدانان در بيان عناصر مال معتقد است: لامال جيـزى مادى يا معنوى است كه به شخصى اختصاص داده شــده يـا قابـل

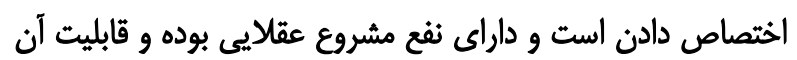
را داشته باشد كه در مصب معاوضه و مبادله قرار كيرد و نهايت اينكه

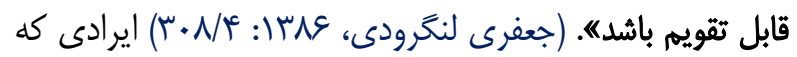

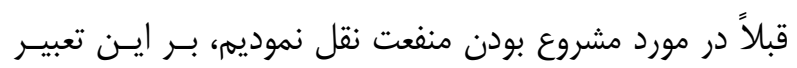

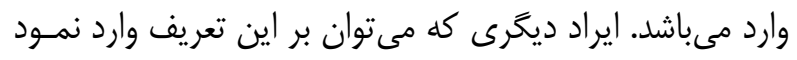

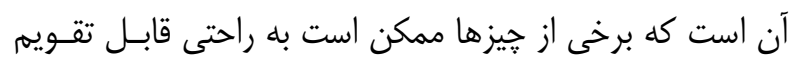
نباشد اما مال تلقى كردد. نكته ديغرى كه حقوقدانان در بيان عناصر مـال كفتـهانـــ ايسن است كه لامال، حاكى نيست و هر خه كه حاكى از واقعيتى باشد آن

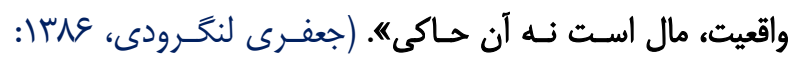

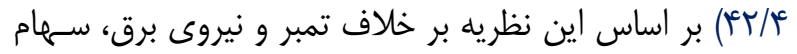

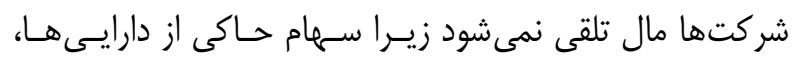
مطالبات و تعهداتى شركت ذيربط مىباشد. برخى از حقوقدانان،

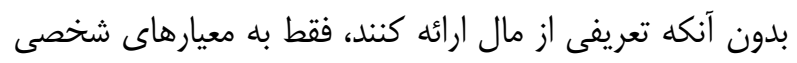

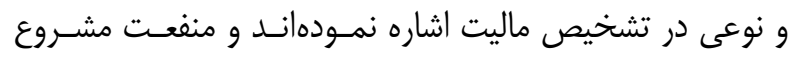
عقلايى را تخصيصـى بــر مـورد معاملـه محسـوب نمـودهانــد.

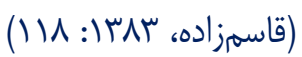

يكى ديگر از حقوقدانان، در تعريف مال مى گويد: لامال عبارت از

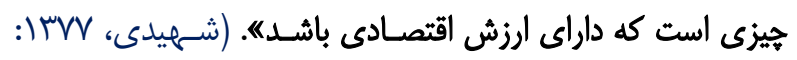

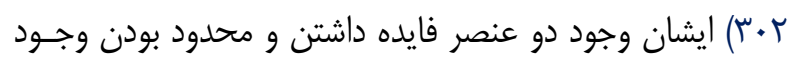

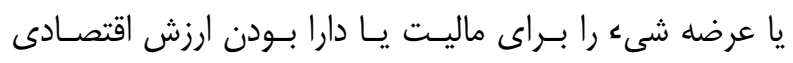

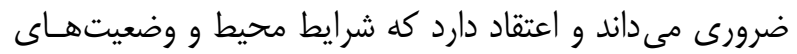

بر اطلاعات خود تسلط دارد و اين تسلط در نتيجه اعمـال حـق

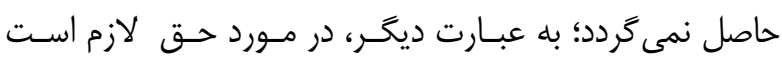
مقتضى از قبل موجود باشد كه در اينجا مفقود است.

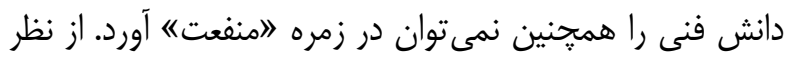

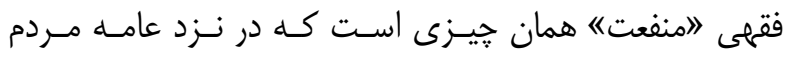
متداول شده و به همين دليل به ذكر تعريفى از آن نيرداختـه و

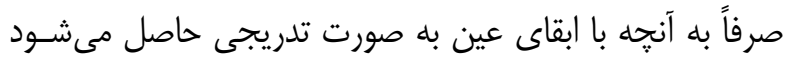

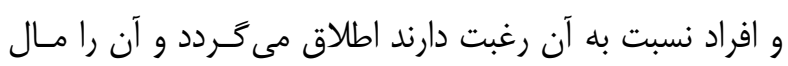

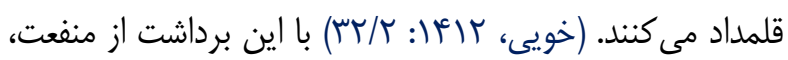
دانش فنى جزء منافع اعيان قرار نمى گَيرد. سـؤالى كـه مطـرح

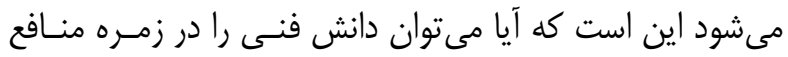

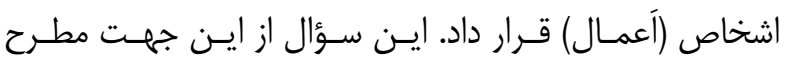

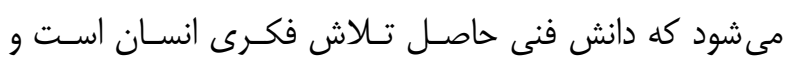
بنابر اين جزء منافع اشخاص محسوب مى دشود. برخى از فقهما در

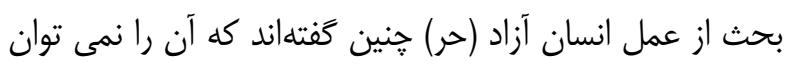

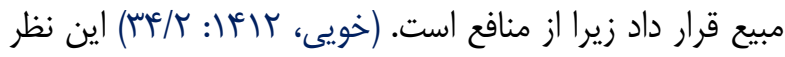

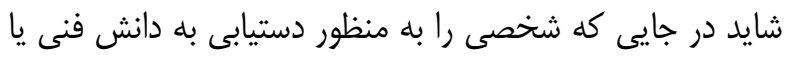
آموزش آن استخدام مى كنند، قابل يذيرش باشد اما در ما نحـنـ

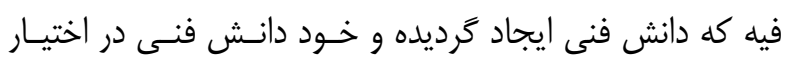

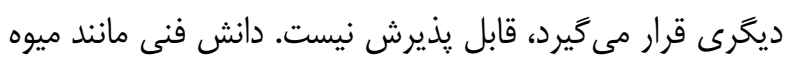

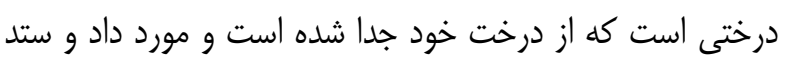

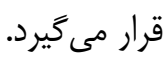
با توجه به مطالبى كه در خصوص حق و منفعت از منظر فقهى

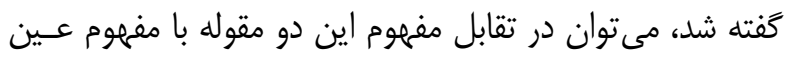

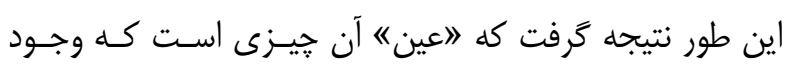

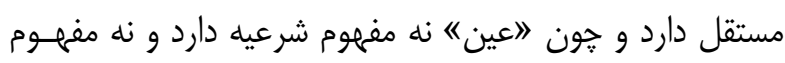

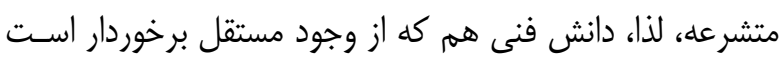

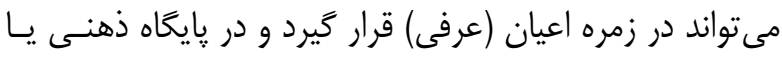

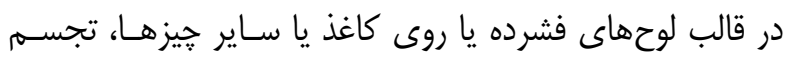
يافته و مستقر شود. اشكال جدى در مورد عين بودن دانش فنى آنست كه لاعينين ستود. در نظر فقها، آن جيزى است كه وجود خارجى داشته و برخوردار

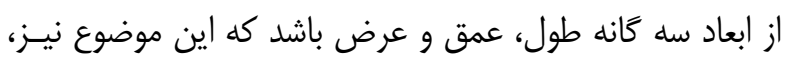




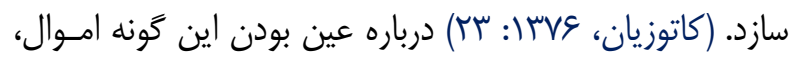

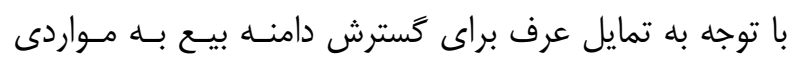
جون سرقفلى و حق اختراع مى گويند: لاز اين تمايل عـرف بايـد سود برد و انتقال كالاى در جريان (مانند نيروى برق) را بيع شمرد، و و وان رويه قضايى را به سويى كشاند كه انتقال مالكيت حق و اموال غير مادى نيز در تعريف بيع بكنجد و قيد لاعينه تنها براى خروج اجاره

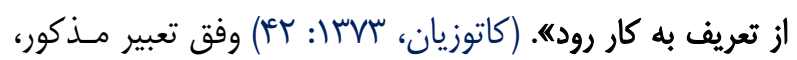
بايد كفت اموال غير مادى جون وابسته سـاير امـوال محسـوب نمى شوند، عين هستند.

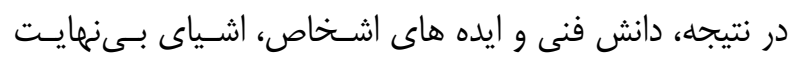

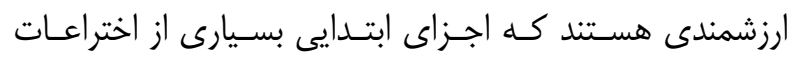

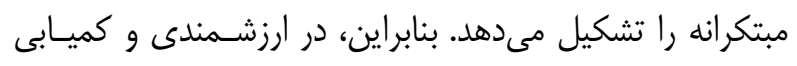

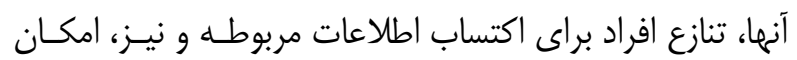
رفع نيازهاى افراد به واسطه دانش فنى ترديـدى وجـود نــارد.

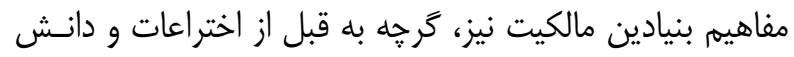
فنى ييجيدهاى كه اكنون وجود دارد، برمى گردد، امـا حمايـت از اين يديده اجتماعى در قالب قوانين مالكيتى موجود، يكنواختى و وديداي

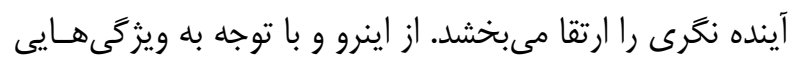
كه براى دانش فنى در ابتداى مبحث نخست برشمرديم و نيـز،

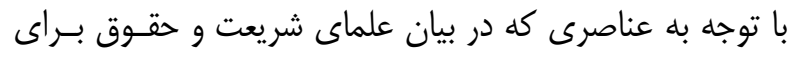
ماليت اشياء عنوان شد، دانش فنى مال به حساب مسى آيـد و در نهايت اينكه، با توجه به دلايل ابراز شده، اين نوع از اطلاعـات

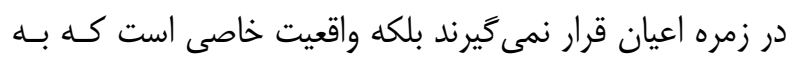
كمى آن مىتوان ايدههاى افراد را مورد حمايت قرار داد.

\section{r- مبانى حمايت از دانش فنى}

منطق اقتصادى و دليل اصلى حمايست از دانـش فنسى و اسـرار

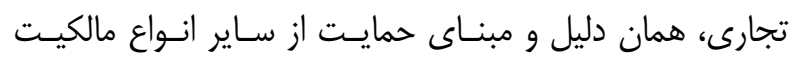

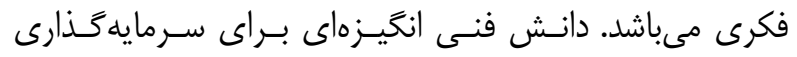

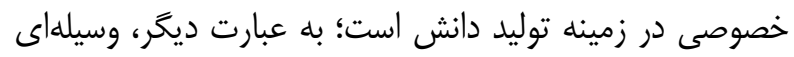
خواهد بود كه به واسطه آن مىتوان جلوى استفاده ديخران را از

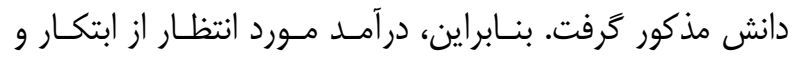
اختـراع خـود را افـزايش داد. حمايـت از دانـش فنـى در واقـع
شخصى و اجتماعى با تنوعى كه دارند به ماليت مفهـوم نسـبى

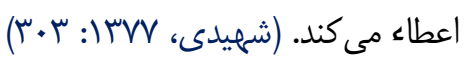

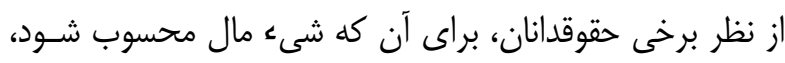

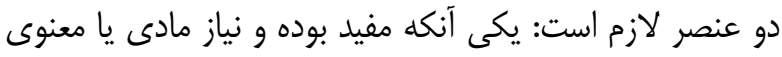

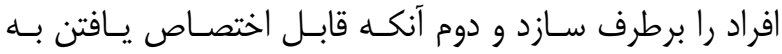

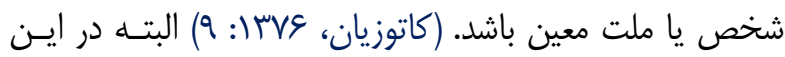

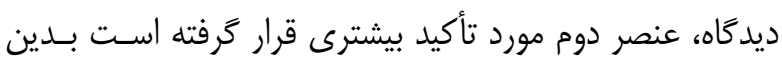

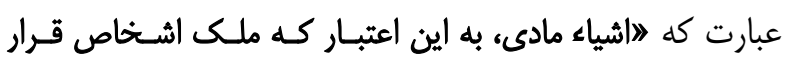

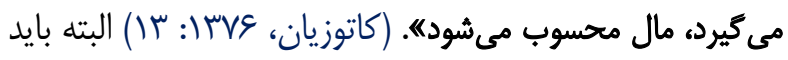
به اين نكته توجه كنيم كه ملكيت بعد از ماليـت اسـت و شـايد اين عبارت خالى از اشكال نباشد.

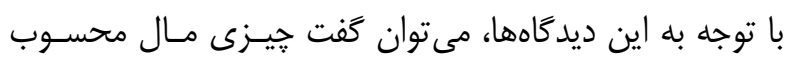
مى شود كه قابليت اختصاص داشته، واجد ارزش اقتصادى بوده، و داراى نفع عقلايى و مشروع باشد و نيازى از نيازهاى افـراد را بر آورده سازد. معيار تشخيص وجود عناصـر مـذكور هـمـ عمـــاً شخصى مىباشد. برخى از اساتيد حقوق، اموال را بــه دو دسـته مـادى و معنـوى

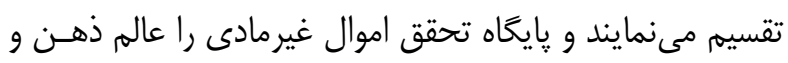
انديشه مى دانند، هرجند كه ممكن است با ابزار مـادى و عينسى

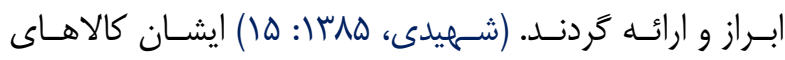

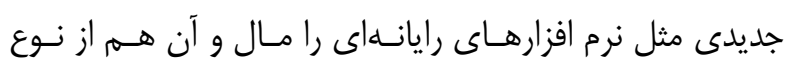
اموال عينى مى دانند. براى مال بودن اين گَونه كالاها، به ارزش

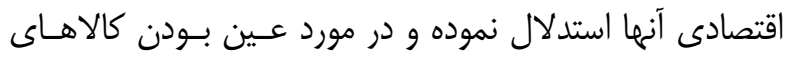
مزبور بيان مى دارند كه اين كالاها منفعت محسوب نمسى شـوند

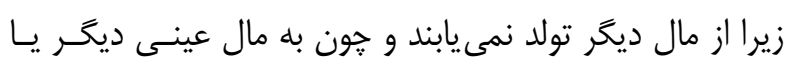

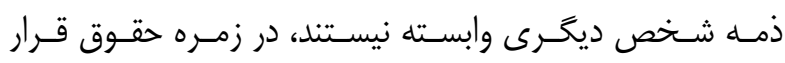

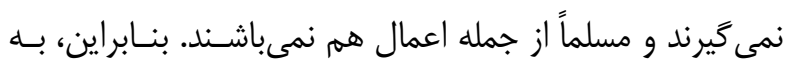
نظر مىرسد كه اين كونه از كالاها اعين" هسـتند. (شـميدى،

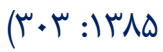

برخى نويسندكان ديخر، آفريدًار واقعى حقوق معنوى را اجتماع

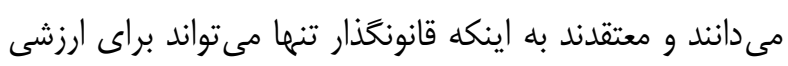

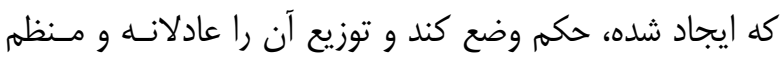


أمريكا نيز، در اغلب مـوارد دليلـى كـهـ بــراى حمايـت از اسـرار

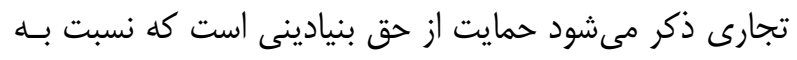

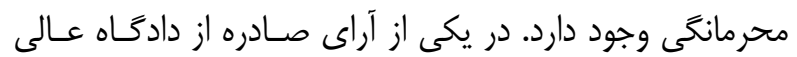

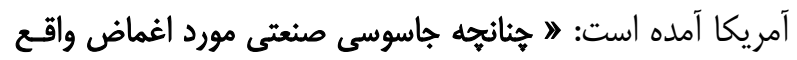
كردد يا ترجيح داده شود، بنيادى ترين حق انسانى، كه محرمـانكى هاسلى

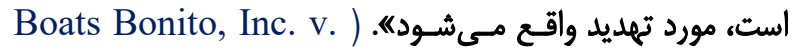

(Thunder Craft Boats, Inc, 1989 آنجهه كَفته شد را مى توان انكخيزههايى دانست براى آنكـهـ بتـوان

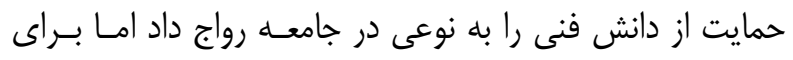

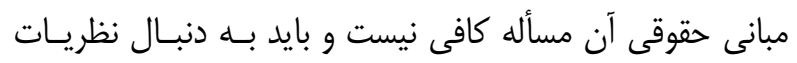

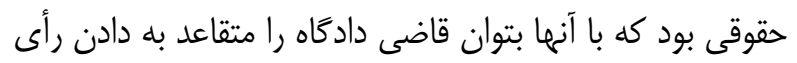
به نفع دارنده دانش فنى كه به واسـطه سـوء اسـتفاده ديخـران

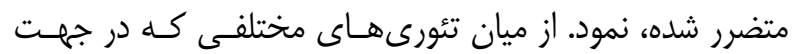

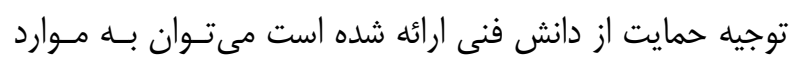
ذيل اشاره كرد.

\section{r-1 - تئورى تعهد قراردادى}

مطابق اين نظريه، تعهد عدم افشاى اطلاعات محرمانسه عمومـاً برخاسته از بطن رابطـهـ قراردادى ميـان مالـى دانش فنـى و اشخاصى است كه اطلاعات مذكور به آنها منتقل مى

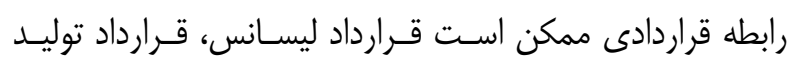

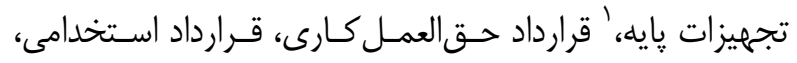
قرارداد مشاركت انتفاعى (جوينت ونجر) و غيره باشد. توافق محرمانكىى مىتواند صراحتاً يا به طور ضمنى، جداخانه يـا در ضمن قرارداد، قيد گردد. وجه التزام يا جريمه قراردادى نيـز، مىتواند اين تعهل را همراهى كند. بنابراين، در بسـيارى رويـهـهاى قضايى همين اندازه كه قراردادى بين طرفين وجود داشته

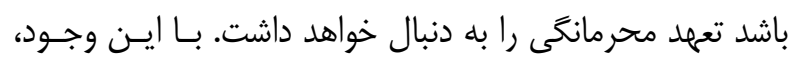

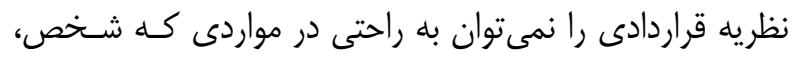
منافعى را بلا جهت از دانش فنسى كسـب كـرده و هـيجيج رابطـهـ قراردادى با دارنده ندارد اعمال نمود. براى مثال، در موردى كـهـ

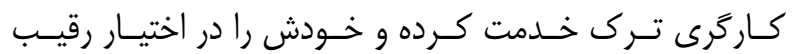

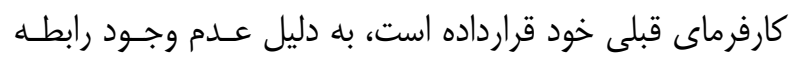

1 - OEM Contract (Original Equipment Manufacturer Contract)
هزينهاى است كه به موجب آن اسـتفاده ديخـــان از اطلاعـات

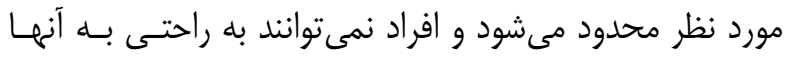
دست ييدا كنند. برخى از نويسندكان، دليل حمايت از دانش فنى را در يرتو انخيزيزهاى محرك براى اختـراع كـردن دانسـتهانــد، (Régis, 1976: 9) نمودهاند كه اگر دليل وجود قوانين مربوط به دانش فنى، ايجـاد

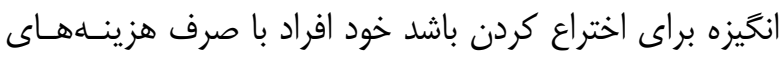

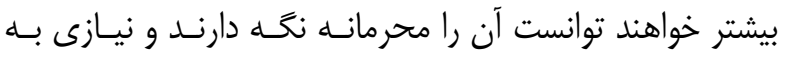
وضع قوانين جديد نخواهد بود. (Risch, 2007: 45) تعادل ميان انحصار و محدود كردن رقابت، در خصـوص تعيـين نوع اطلاعاتى كه بايد حمايت شود و طول دوره حمايت و اينكه

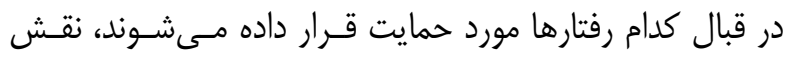
اساسى و مهمى دارد. در اين زمينه، خواهـان دعـوا بايـــ رفتـار

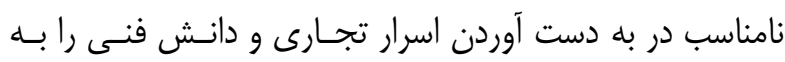

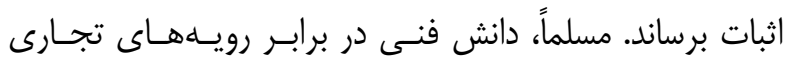
صادقانه، نظير مهندسى معكوس يا فعاليتهاى توسعه و تحقيق مستقل قابل حمايت نخواهد بود. عـلاوه بــر اينكـهـ حمايـت از دانش فنى به سرمايه كذارى در تحقيق و توسعه كمى مى كنـد،

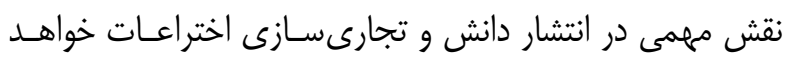

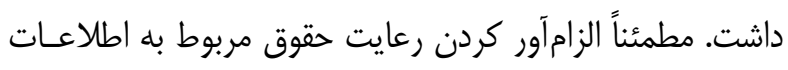
محرمانه باعث انعقاد قراردادهاى ليسـانس مسىشـود و احتكـار دانش فنى معتبر را محدود مىنمايد. عـلاوه بـر ايـن، خسـارات ييشبينى شده براى سوء استفاده از دانش فنى ديخــران باعـث

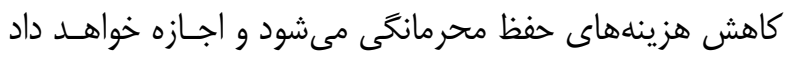

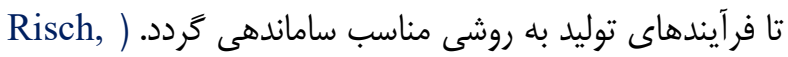
65 :2007 دليل ديخر حمايت از دانـش فنسى، بهبــود اخـلاق حرفهاى كسب و كار مىباشد. مبناى قانون رقابت غيرمنصـفانه در آلمان جلوگيرى كلى از اقـداماتى اسـت كـهـ خـلاف اخـلاق حسنه در زمينه قراردادهاى تجارى تلقى مىشود. ( Czapracka

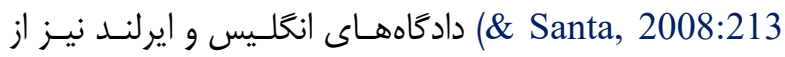
اصول انصاف براى حمايـت از محرمـانكى اسـتفاده مسى كنــــ. House of Spring Gardens Ltd. v. Point Blank ) (Ltd., 1983; Fraser v. Evans, 1969 
استناد اين دارا شدن اقامه مى گَردد فارق از هرَّنه قـرارداد يـاــا اغواى يكى از طرفين به نقض، خواهد بود.

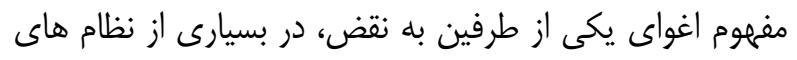

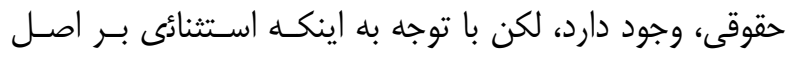
نسبى بودن قراردادهـا اسـت در عمـل اغلـب اجـرا نمسى شـود.

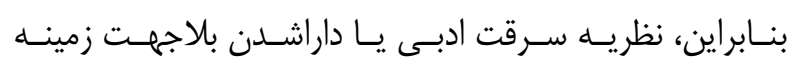

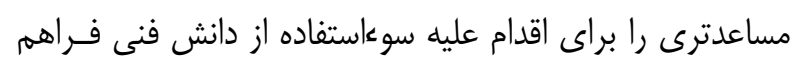

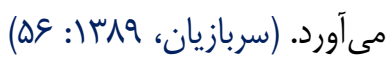
نظريه مذكور تحت عنوان سرقت ادبى در آمريكا و تحت عنوان اقدام عليه رويههاى تجارى صادقانه در ارويا مورد يذيرش قـرار

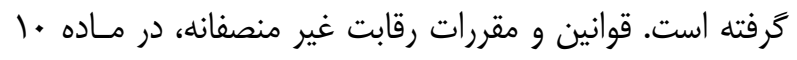

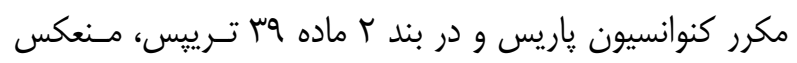
كرديده است. نظريه سرقت ادبى به درستى بر اين واقعيت كه دانسش فنسى از جمله دارايى فرد محسوب مىشود، تأكيد مى كنـد؛ در واقـع بـر

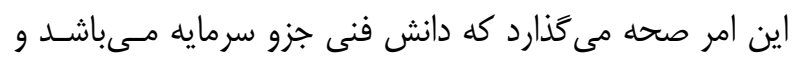

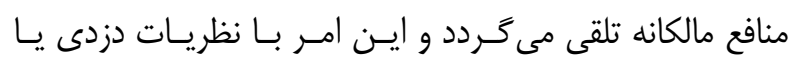

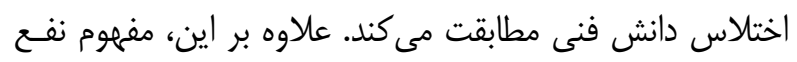

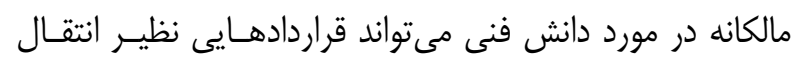

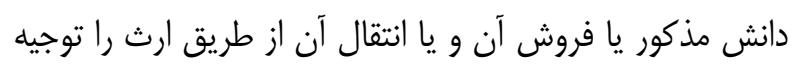

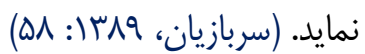
به هرحال، آنجّه لازم است موضوعيت داشته باشـد، حمايست از

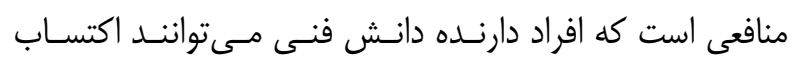

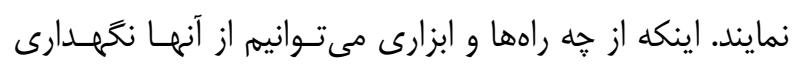

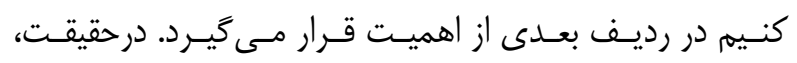
مىبايست آن راهحلى مورد يذيرش و اعمال قرار گيرد كه با آن آن بتوانيم به نحو بهتر و معقولترى از دانش فنى حمايت كنيم.

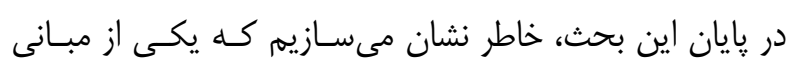

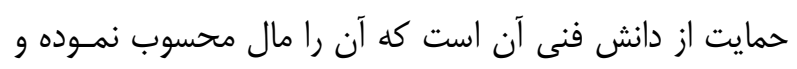

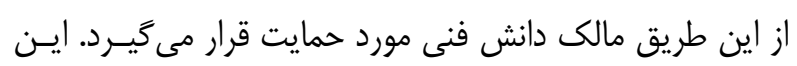

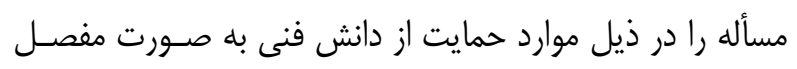

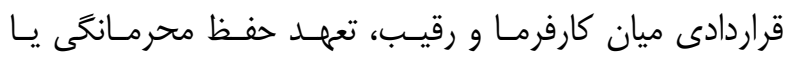

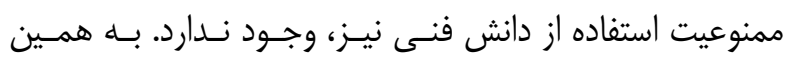
ترتيب است فرضى كه در آن منتقل اليه به صورت ناروا دانـش لـ

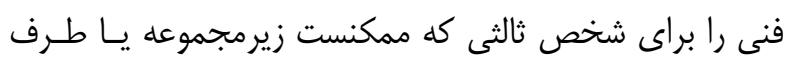

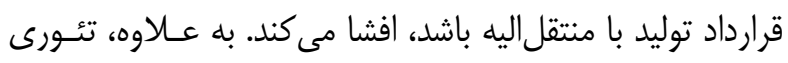
مذكور اين مسأله را توجيه نمى كند كه هرا بسيارى از كشـورها

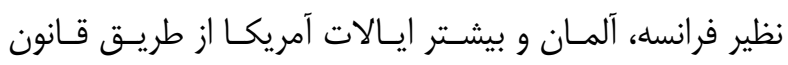

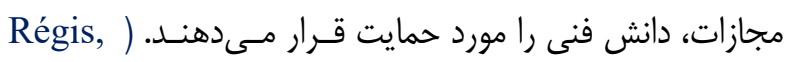

(1976: 9

\section{r-r- (- نظريه رابطه امانى}

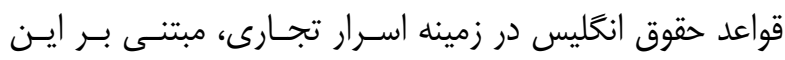
نظريه است كه حقوق، رعايت محرمانكى را لازم مى داند. براى لئه

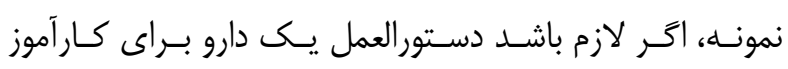
داميزشكى افشا شود، تعهد محرمانكى حتى در صـورت فقـــــان

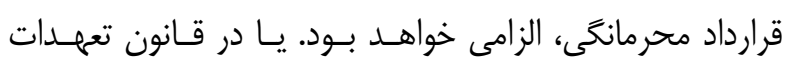

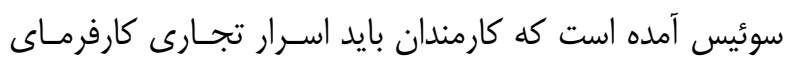

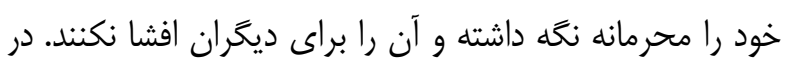
توجيه مبناى اين تعهدات به رابطه امانتدارى اشاره شــده اسـت. به همين ترتيب، در مورد حفظ اسـرار داورى، بــه همـين شـيوه

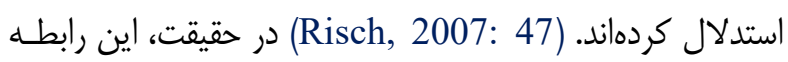
قراردادى ميان افراد نيست كه باعث تعهد محرمانكى مىشـودة، هرا كه ممكن است افراد هيج كَونه قصدى نسبت به اين تعهـــ

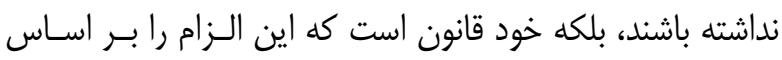
رابطه امانى در نظر ترفته است.

r-r- نظريه دارا شدن بلا جهت

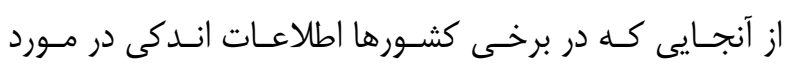

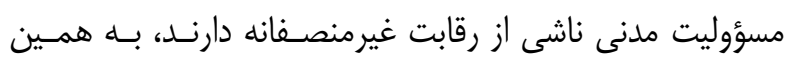
جهت رويه قضايى آنها سوءاستفاده از دانش فنسى را بــه عنـوان

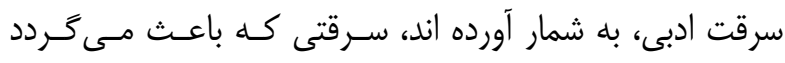

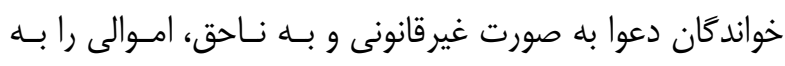

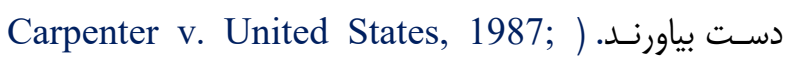
Osborn v. Boeing Airplane Co., 1962; Matarese v. (Moore McCornack Lines, Inc., 1946 دعوايى كه به 
امكانيذير است، اما راهحلهاى ذيل بعضاً جهت حمايت از آن مورد توجه واقع شدهاند.

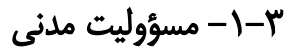

مسؤوليت مدنى منتفع غيرقانونى دانش فنى، به صورت مستقل از مسؤوليت جزايى يا همراه با آن، مورد ييخيرى قرار كَرفته است. شايد در بادى امر، اين عبارت گزاف به شمار آيد خرا كه مهرك هر كسى حق دارد در قالب آزادىهايى كه دارد فنونى كه قابل تخصيص به صورت انحصارى نمى باشند را مورد استفاده قرار

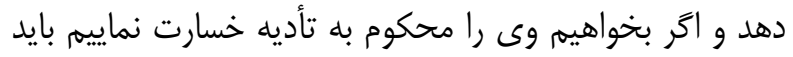
تمامى افراد را هر روز به دادكاه فرا خوانيم. به عبارت ديكر، استفاده و اجرايى كردن فنى كه غيرقابل تخصيص به صورت انحصارى توسط دارنده آن است به خودى خود منشأ مسؤوليت نخواهد بود. نسخه بردارى از جيزهايى كه مورد حمايت قرار

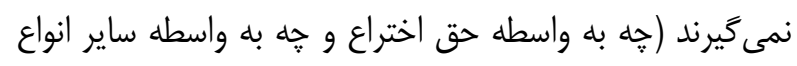
مالكيتهاى فكرى كه در مورد آنها مصوبات قانونى وجود دارد) تجاوز به حقوق ديگران محسوب نمىشود، بلكه در قالب آزادىهاى تجارى و صنعتى قرار مى ييرد. اما حق مذكور را

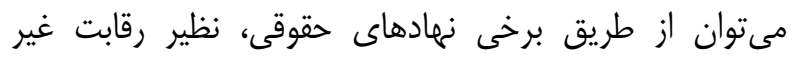

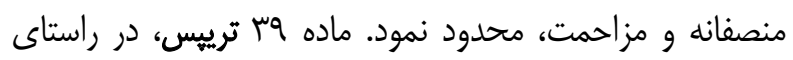

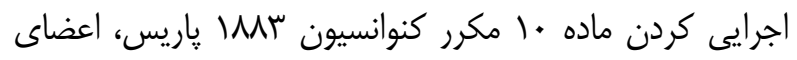
عضو خود را موظف مى كند تا از رقابتهاى غيرمنصفانه ممانعت به عمل آورند. در حقوق فرانسه به اين صورت است كه افراد مىتوانند حق خودشان نسبت به نقض حقوقى كه در

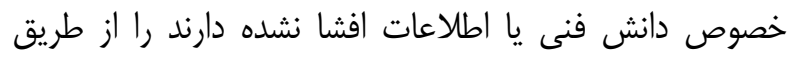
طرح دعواى رقابت غيرمنصفانه يِيَيرى نمايند. البته در اين خصوص لازم است كه اركان مسؤوليت مدنى به اثبات برسد (تقصير خوانده دعوى، كه علت مستقيم خسارتى است كه وى لهى تقاضاى جبران آن را دارد، ورود خسارت و رابطه سببيت).

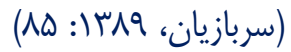
عنصر تقصير منتفع از دانش فنى مىتواند عبارت باشد از اينكه

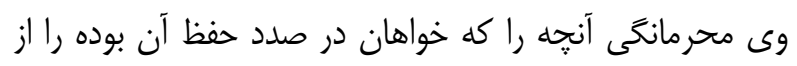
بين برده است. به عبارت ديخر، اگر دارنده دانش فنى هيج گَونه اقدامى براى حفظ محرمانه ماندن دانش فنى خود انجام ندهد،
توضيح خواهيم داد. فلذا از بيان مجدد در اين قسمت خـوددارى مى كنيم.

\section{r- شيوههاى حمايت از دانش فنى}

ايدهها كه عمدتاً در قالب دانش فنى صنعايت رانشى صنى، اطلاعات، اختراعات و علائم منحصر به فرد محصول بروز مىيابند، محصول فعاليت ذهنى محسوب مىشوند و در اغلب موارد، به اين صورت است كه نفع قابل توجهى را نيز به همراه دارند. اين

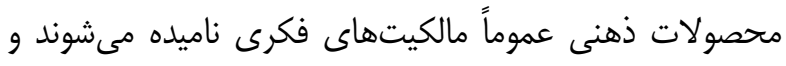

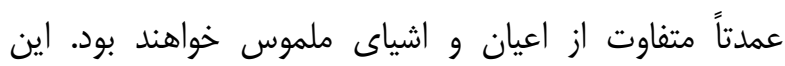
محصولات و دادهاى ذهنى مىتواند به صورت همزمان و توسط جندين فرد تصاحب و مورد استفاده قرار گيرد، آنجنانكه اين קند نفر مىتوانند اين محصول ذهنى را در هند موضع كاملاً متفاوت بهكاركيرند. اين در حالى است كه اين دو دو مسأله به هيج عنوان در مورد اشياى ملموس نمىتواند صادق باشد، يعنى نه مىتواند همزمان توسط دو شخص مورد استفاده و

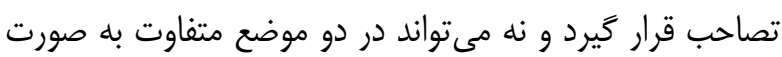

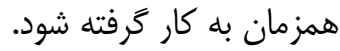
به علاوه، شاخصههاى يك ايده را نمىتوان معين كرد و نيز كاربرد آن را نيز نمىتوان اداره نمود. محصول ذهنى براى يهى

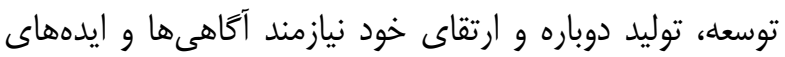
قبلى مىباشند. ارزش و كارآيى يك محصول ذهنى مىتواند به واسطه دانش شخصى فردى كه ايده يا اختراعى را براى اولين بار ياد مى گيرد ارتقا يابد. بديهى است كه مشكل بتوان ايدهاى را از اطلاعات قبلى و دانش خاص شخصى كه آن ايده را فرا

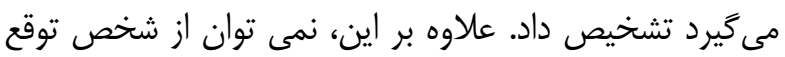

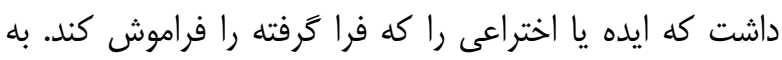

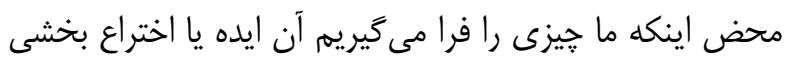

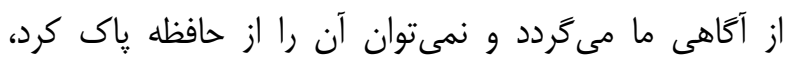
(آن كَونه كه در مورد حافظه كامبيوتر اين امكان وجود دارده دارد). بر عكس اين، در مورد اموال عينى يا ملموس مىتوان جلوى شخص را كرفت تا از اموالى كه ديخرى مالى آن شده، استفاده

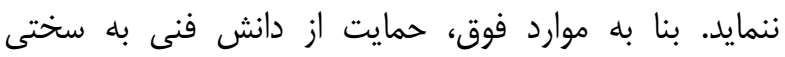


مسأله تصرف يا غصب يا تجاوز به دانش فنى متعلق به

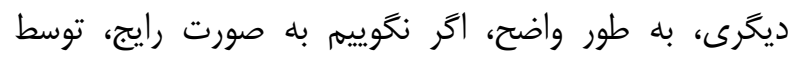
اشخاص خارج از شركت كه مبادرت به اعمال جاسوسى صنعتى يا تجارى مىنمايند صورت مىيذيرد و به صورت معمولتر، اين رقباى شركت هستند كه به واسطه تبانى با اعضاى يرسنلى شركت به قصد دستيابى به اطلاعات محرمانهاى كه در اختيار

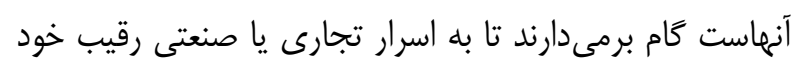

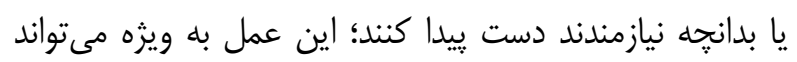
در مورد اشخاصى اتفاق بيفتد كه قبلاً مسؤوليت حفظ اسرار شركت يا مجموعه مورد نظر به آنما سيرده شده بوده است.

\section{r-r- حمايت قراردادى از دانش فنى} دارنده دانش فنى اغلب به اين سمت هدايت مىشود كه

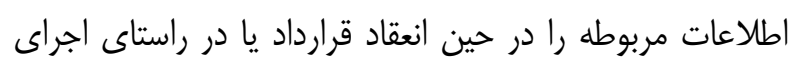
قراردادى كه منعقد نموده، افشا نمايد. بنابراين، وى با اين اقدام خود خطر از دست دادن مديريت و مالكيتى كه نسبت به اين

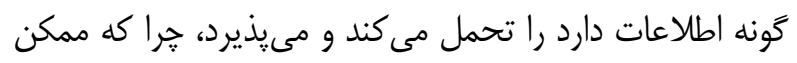
است طرف قراردادى در صدد افشا يا سوء استفاده از آن اطلاعات برآيد. اشخاص ذينفع تلاش مى كنند كه با تعهدات قراردادى كه محرمانكى يا رازدارى ناميده مىشوند از اين گُونه

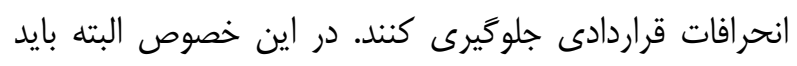
شروط عدم رقابت هم مورد بررسى و لحاظ قرار گيرد. اين گَونه

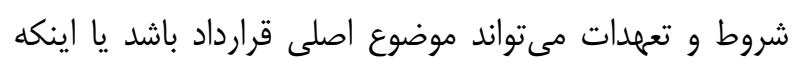

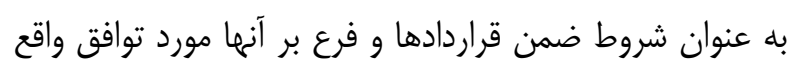
(Buhler, 2002: 361) كردن تعهدات محرمانگى مذكور، به طور ويزه در اسناد ييشقراردادى :مرد كه در طول مذاكرات منعقد مى قرارداد مورد تعهد و توافق طرفين واقع مىشود. ( Buhler,

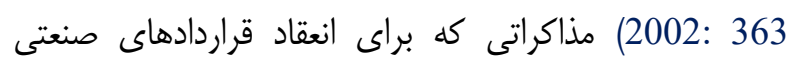
صورت مىيذيرد، تقريباً به اين صورت است كه ناجاراً لازم

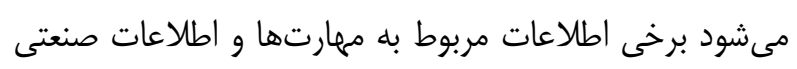

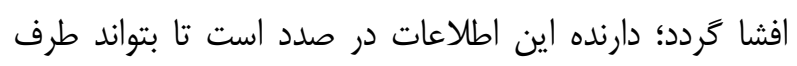

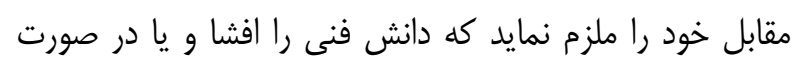

به طورى كه به راحتى در دسترس ديگًران قرار كيرد و

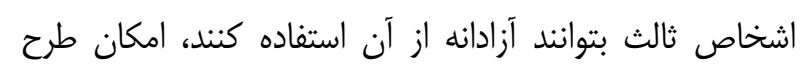

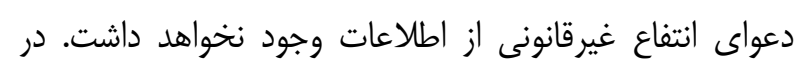

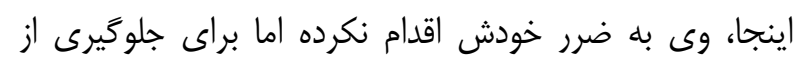

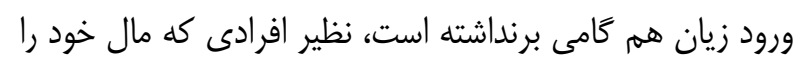

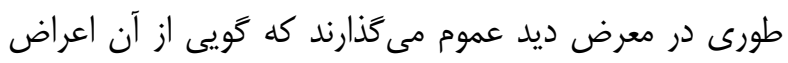

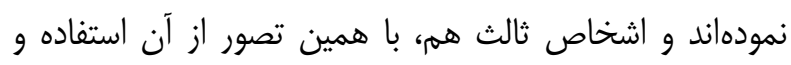

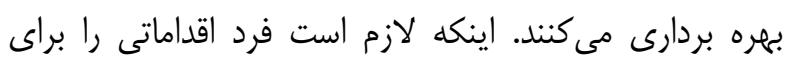
حفظ محرمانكى اطلاعات خود انجام بدهد تا بتواند بعداً در برد

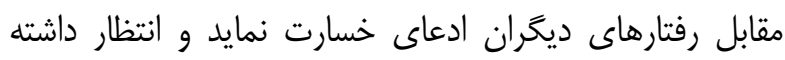
باشد كه مقررات حقوقى و ضابطين قضايى از وى حمايت به

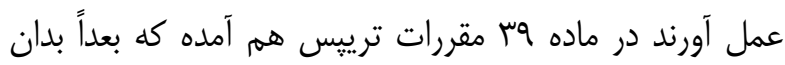

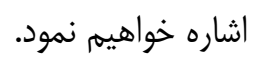
دارنده دانش فنى در صورتى كه قصد اقامه دعواى مسؤوليت

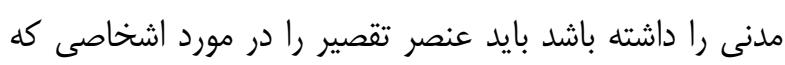
مجوز دسترسى به دانش فنى را صادر نموده يا از آن بهره

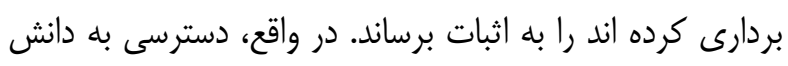
فنى در صورتى ناعادلانه محسوب مىشود كه اوضاع و احوال و شرايط حاكم، حكايت از نقض روشهاى مشرى مشروع رقابت داشته باشد. در عمل مى توان كفت كه اقدامى تقصير محسوب مى شودان

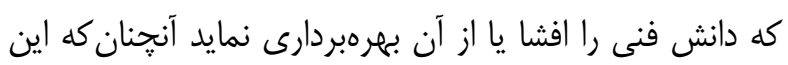
افشا و بهره بردارى باعث خسارت به دارنده دانش فنى مذكور

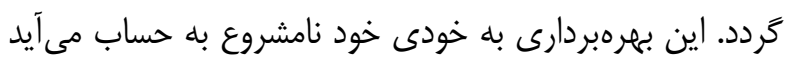

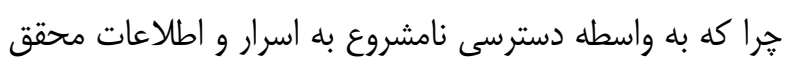

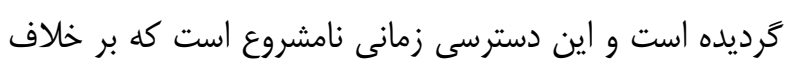
اراده صاحب آن كه قصد داشته محرمانه باقى بماند، به وجود آمده باشد. در هر حال، به صرف اينكه محصولات يك شركت

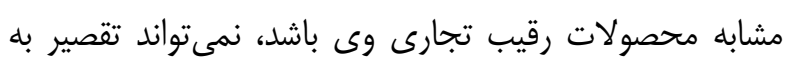

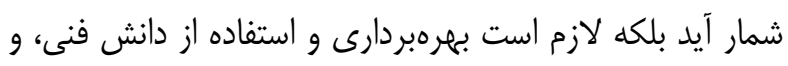

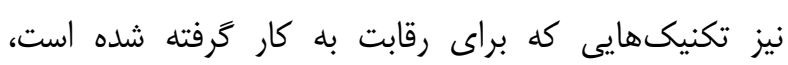
متقلبانه و غير منصفانه بوده باشند. 
باشند. ممكن است در اين شروط آمده باشد كه متعهد لازم است تعهد محرمانگى را به همكاران يا مشتريان خود نيز يادآور

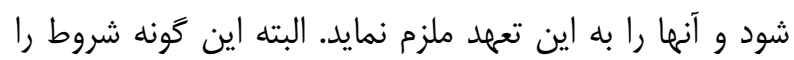
مىتوان با منع واگذارى قرارداد اصلى، تقويت كرد. نكته قابل توجه اينكه همواره به اين صورت نيست كه تعهد محرمانكى به طور صريح و كتبى عينيت بيابد، بلكه در برخى موارد اين تعهد با رفتار دارنده محقق مىشوداد، براى نمونه دارنده

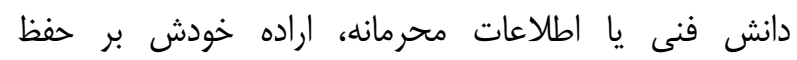
محرمانكى را با درج عبارات "امحرمانه" يا لراز" بر اسناد داخل شركت يا كارخانه يا آزمايشحاه و يا محل كار، ابراز مىدارد و همين امر مىتواند مبناى تعهد محرمانحى را بنيان كذارد.

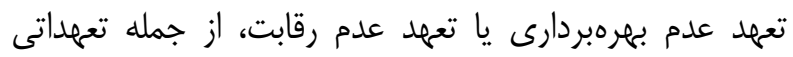

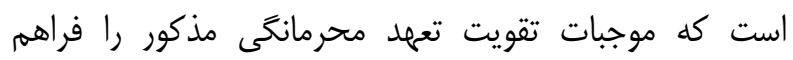
مى آورد. اعتبار اين شروط به موجب حقوق قراردادها مىباشد و وله در كشورهايى كه مقررات عدم رقابت وجود دارد، حقوق رقابت مىتواند مبناى شروط مذكور قرار خيرد. عدم اجراى تعهدات محرمانكى، تعهد جبران خسارت وارده بر متعهدله را به دنبال خواهد داشت. در حقيقت نمىتوان اجراى عين تعهد را از متعهد خواست، هرا كه راز افشا شده را نمىتوان باز گرداند. در مورد بهرهبردارى غيرقانونى و خلاف توافقاتى كه رها

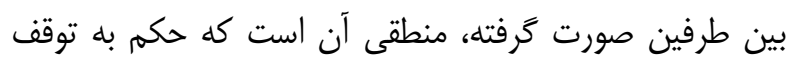
اجبارى اقدامات در حال اجرا داده شود.

\section{نتيجه كيرى}

دانش فنى و ايدههاى اشخاص، اشياى فـوقالعـاده ارزشـمندى

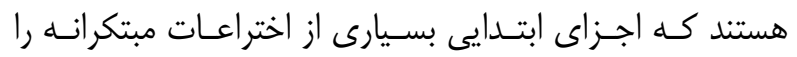

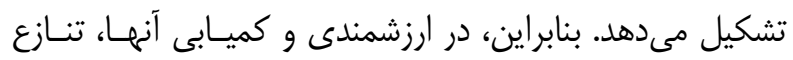
افراد براى اكتساب اطلاعات مربوطه و نيز، امكان رفع نيازهـاى افراد به واسطه دانش فنى ترديدى وجود ندارد. مفاهيم بنيـادين

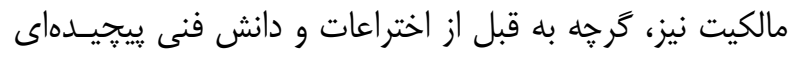
كه اكنون وجود دارد، برمى كردد، امـا حمايـت از ايـن الحاقـات

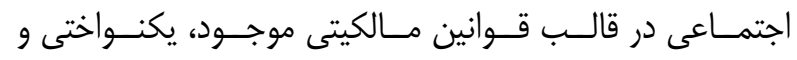

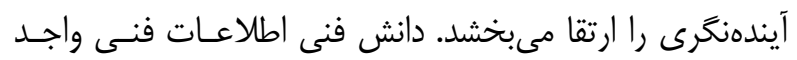

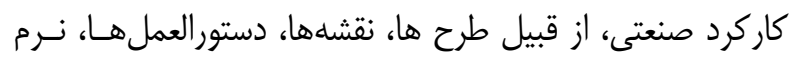

شكست مذاكرات از اطلاعات داده شده بهره بردارى نكند كه اين تعهدات ممكن است شكلهاى مختلفى به خود بحيرد. (Brooke, 1994: 133) توافق نسبت به حفظ محرمانكى در بيشتر موارد از شروط ضمن قرارداد به حساب مىآيند. موضوع اصلى قراردادهاى حاوى شروط مزبور، هر جيزى ممكن است باشد: موضوع قرارداد

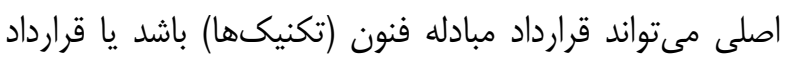
تحقيقاتى يا ارائه خدمات مديريتى در حوزه انفورماتيك يا ارائه خدمات ييمانكارى در فرانشيز تجارى يا صنعتى براى تأسيس حديس مجموعه صنعتى و غيره. تعهدات مزبور، ممكن است به نفع كارفرما و به عهده كارمند در

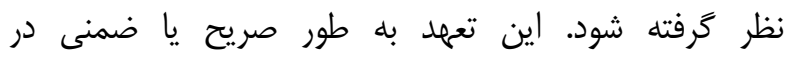
قراردادهاى كار انفرادى يا جمعى و يا جزو مقررات كاركاه كنجانده مى شود و نيز ممكن است به موجب تعملد امانتدارى كه

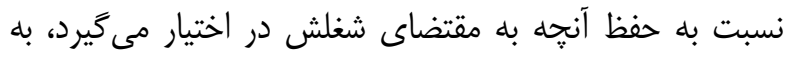
عهده دارد بر وى تحميل گردد. عدم رعايت اين تعهد ممكن است موجب مسؤوليت مدنى يا جزايى و نيز مجوز اخراج وى قلمداد شود. مدت زمان اعتبار اين شروط تا لحظه قطع روابط قراردادى خواهد بود. افشاى اطلاعات محرمانه بعد از زمان انفصال از خدمت، مىتواند موجبات تقصير و در نتيجه مسؤوليت مدنى كارمند را فراهم آورد، البته اين در صورتى است كه بين طرفين قراردادى بر خلاف اين امور توافقى نشده باشد. شروط موضوع محرمانكى، دامنه تعهد مذكور را مشخص

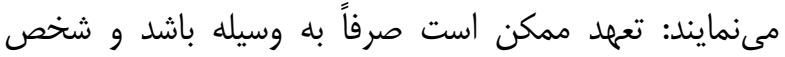
موظف گردد كه تلاش خود را جهت محرمانه باقى ماندن اطلاعات مبادله شده، انجام دهد. و نيز ممكن است تعهد به روده نتيجه باشد كه در اين صورت، مسؤوليت افشاى اسرار به عهده وى خواهد بود، مخر آنكه اثبات نمايد افشاى اطلاعات مذكور از تحت كنترل وى خارج بوده است. شروط همجنين در مورد

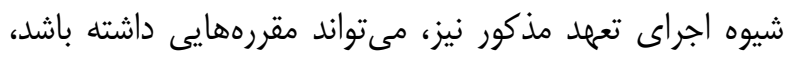

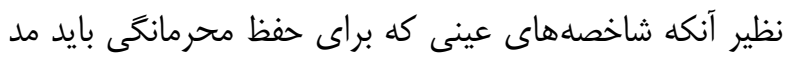

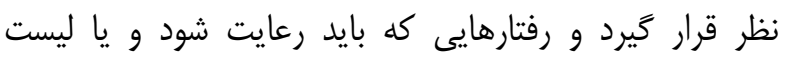
افرادى كه مىتواند اجازه دسترسى به دانش فنى را داشته 
رابطه امانى اشاره كرد. البته شيوههاى حمايت از دانشفنى

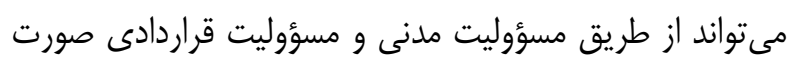
بخيرد.

ملاحظات اخلاقى: موارد مربوط به اخلاق در يزوهش و نيز

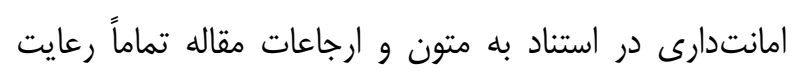

تعارض منافع: تدوين اين مقاله، فاقد هرگَونه تعارض منافعى

$$
\text { بوده است. }
$$

سهم نويسندكان: نخارش مقاله بر اساس اصول نغارش حقوقى، تماماً توسط نويسنده انجام كرفته است.

تشكر و قدردانى: از تمامى كسانى كه در تهيه اين مقاله ما را يارى رساندند تشكر مىنماييه.

تامين اعتبار يزوهش: اين يزوهش فاقد تامين كننده مالى بوده است.
افزارها و مشاوره هاى مهندسى، مسى باشـــــــهـ مسىتـوان بــهـ

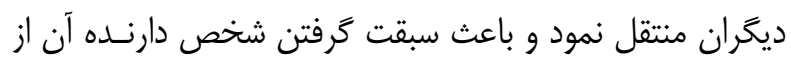

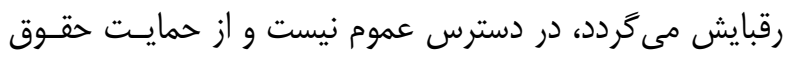

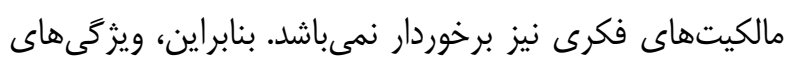

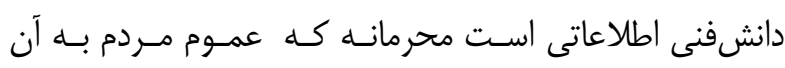

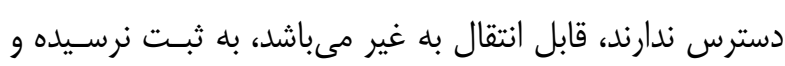

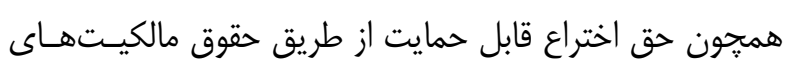
فكرى نيست، از كاركرد عينى برخوردار است و قابل شناسايى و تشخيص مى باشد. بنابراين، دانشفنى متمايز از مقولههايى نظير بردي

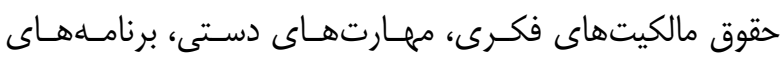
كامييوترى و اطلاعات تجارى مى باشد. با توجه به ويثگى هايى كه براى دانش فنى شمرده شد و نيز بات باسل

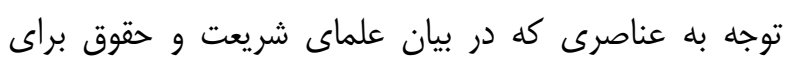
ماليت اشياء عنوان شد، نتيجه مىشود كه دانش فنى من مال بـ به

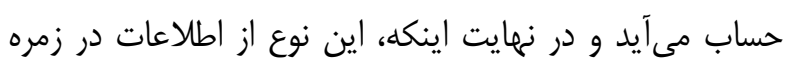

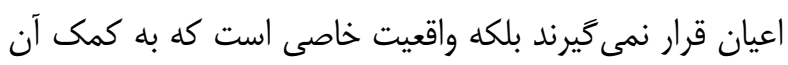

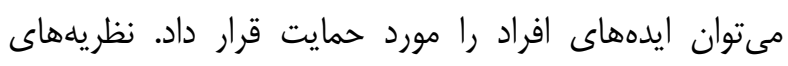
مختلفى براى حمايت از دانشفنى عنوان شدهاند كه از إز جمله

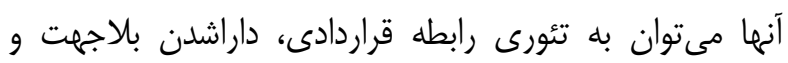


منابع و مآخذ

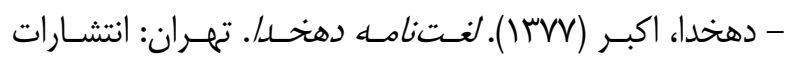

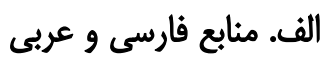

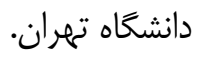

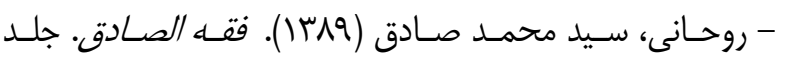

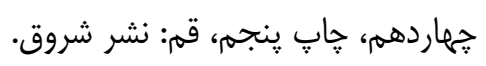

- سربازيان، مجيد (9) - (1). قراردادهاى بين/الملى انتقال دانشش

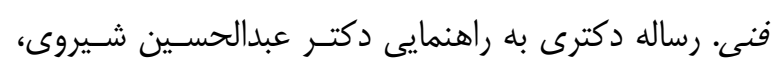
قم: يرديس فارابى دانشعاه تهران.

- شبير، محمد عثمان (1) (1) (I). المعاملات المالئُ المعاصرة فـى الفقه الاسلامى. اردن: دار النفائس.

- شهيدى، مهدى (IrVV). تشكيل قراردادها و تعهدات. تهران:

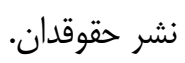

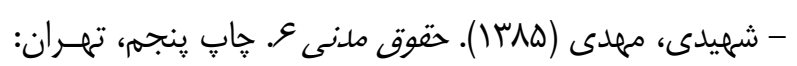

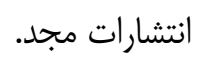

- علهمالمـدى، مرتضـى (هأبا). الاتتصـار. قـم: مؤسسـه نشـر اسلامى.

- عميد، حسن (•وسا). فرهنَ عميل. خاب سى و هشته، تمران: انتشارات اميركبير.

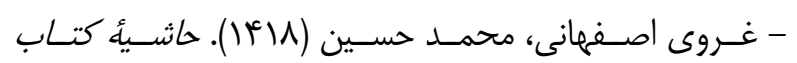
المكاسب. جلد ينجم، قم: نشرمحقق.

- فراهيدى، خليل ابن احمد (ه+عا). العين. جلد هشته، قم:

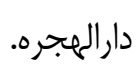

- قاسم زاده، سيد مرتضى (سمبا). اصول قراردادها و تعهــات.

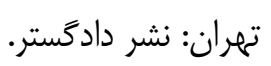

- كاتوزيان، ناصر (سطسا). دوره عقود معين. خاب ينجمه، تهران: شر كت انتشار.

- ابن اثير، مبارك (VVII). النهايه فى غريب الحديث و الاثر. جلد جهارم، قم: انتشارات اسماعيليان.

- ابن منظور، محمد (بىتا). لسان العرب. قم: نشر ادب الحوزه. - بحر انى، يوسف ابن احمد (ه +عا(). حدائق الناظره فسى احكام

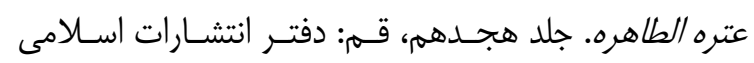
وابسته به مدرسين حوزه علميه قم.

- الجزيرى، عبد الرحمن (19 (1)). الفقه علي المذاهب الأربعـهُو مذهب أهل البيت (ع). جلد ينجم، قم: دار الثقلين.

- جعفرى لنكرودى، محمد جعفر (ع بـا).الفارق. جلـد جهـارم، تهران: انتشارات گنج دانش.

- جعفى لنكرودى، محمدجعفر (IIN)). ترمينولوزى حقوق.

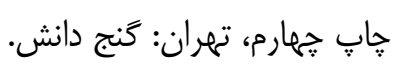
- حكمتنيا، محمود (INAV). مبانى مالكيت فكرى. جـاب دوم، تهران: يزوهشًَاه فقه و انديشه اسلامى. - حكيم، سيد محسن (.• (I). نهج الفقاهه. قـم: انتشـارات بr بهمن. - خمينى، سيد روح اله (ساب(1). كتاب البيع. جلـد اول، تهـران: مؤسسه تنظيم و نشر آثار امام خميني (ره).

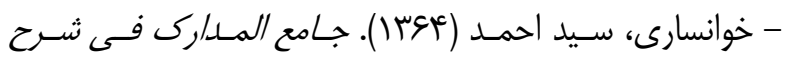
مختصر النافع. جلد سوم، جاٍ دوم، قه: موسسه اسماعيليان. - خويى، سيد ابو القاسم (بأ)(1). مصـباح الفقاهـه (المكاسـب). جلد دوم، قم: مكتب نشر المنتخب. 
- Chavanne, A (1998). "Protecting Trade Secrets: A Worldwide Survey". Managing Intell. Prop Journal, 2(1): 531-545.

- Cornish, W (1996). Intellectual Property: Patents, Copyright, Trade Marks, and Allied Rights. UK: Sweet \& Maxwell.

- Czapracka, A \& Santa, C (2008). "Antitrust and Trade Secrets: The U.S. and EU Approach". Computer \& High Tech. L.J. 24(1): 230-235..

- Régis, F (1976). Le Knowhow: Sa Réservation en Droit Commun. France: NP.

- Risch, M (2007). "Why Do We Have Trade Secrets?". MARQ. INTELL . PROP. L. REV, 11(1): 45-65.

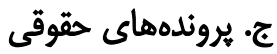

- Boats Bonito, Inc. v. Thunder Craft Boats, Inc. 489 U.S. 141, 155 (1989).

- Carpenter v. United States, 484 U.S. 19 (1987).

- Fraser v. Evans [1969] 1 All E.R. 8 (U.K.).

- House of Spring Gardens Ltd. v. Point Blank Ltd., [1983] F.S.R. 213, 253 (Ir.)

- Matarese v. Moore McCornack Lines, Inc., 71 USPQ 311 (2e Cir. 1946).

- Osborn v. Boeing Airplane Co., 135 USPQ 145 (9e Cir. 1962).

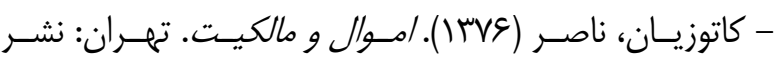

$$
\begin{aligned}
& \text { دادگستر. }
\end{aligned}
$$

$$
\text { - محقق كركى، على (أ - مأ(ا). جامع المقاصد فى شرح القواعـد. }
$$

$$
\text { - مروج جزائري، سيد محمد جعفر (وأ(|). حاشيه عروه الوثقى. }
$$

- منتظرى، حسينعلى (هأ(I). دراسات فى المكاسب المحرمـه.

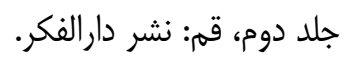

- نائيني، ميرزا محمد (سلّا). حواشى على العروه الوثقى. جلـد

$$
\text { اول، تهران: المكتب المحمديه. }
$$

$$
\text { - نراقى، احمد (هأ(I). مستند الشيعه فى احكام الشـريعه. جلــ }
$$

- يزدي، سيد محمد كاظم ( •أ(1). حاشيه المكاسب. جلد اول،

$$
\text { قم: موسسه اسماعيليان. }
$$

$$
\text { ب. منابع خارجى }
$$

- Brooke, M (1994). The International Sale of Patents and Technical Knowhow. US: Gower Publishing.

- Buhler, M (2002). "Confidentiality Clauses in International Contracts". International Business Law Journal, 3(4): 361-381. 


\section{References}

- Akhound Khorasani, MK (1406). Hashie Makaseb. Tehran: Ministry of Culture Publishing. (Arabic)

- Alam Al-Hoda, M (1415). Al-Entesar. Qum: Islamic Publishing Institute. (Arabic)

- Al-Jaziri, A (1419). Al-Fegh Ala Mazaheb AlArbaea. Vol 5, Qum: Saghlain Publishing. (Arabic)

- Amid, H (1390). Amid Persian Dictionary. $38^{\text {th }}$ ed. Tehran: Amirkabir Publishing. (Persian)

- Bahrani, Y (1405). Hadaegh Al-Nazera. Vol 18, Qum: Islamic Publishing. (Arabic)

- Boats Bonito, Inc. v. Thunder Craft Boats, Inc. 489 U.S. 141, 155 (1989).

- Brooke, M (1994). The International Sale of Patents and Technical Knowhow. US: Gower Publishing.

- Buhler, M (2002). "Confidentiality Clauses in International Contracts". International Business Law Journal, 3(4): 361-381.

- Carpenter v. United States, 484 U.S. 19 (1987).

- Chavanne, A (1998). "Protecting Trade Secrets: A Worldwide Survey". Managing Intell. Prop Journal, 2(1): 531-545.

- Cornish, W (1996). Intellectual Property: Patents, Copyright, Trade Marks, and Allied Rights. UK: Sweet \& Maxwell.

- Czapracka, A \& Santa, C (2008). "Antitrust and Trade Secrets: The U.S. and EU Approach". Computer \& High Tech. L.J. 24(1): 230-235. .

- Dehkhoda, A (1377). Dehkhoda Persian Dictionary. Tehran: Tehran University Publishing. (Persian)

- Farahidi, Kh (1405). Al-Ein. Vol 8, Qum: AlHejra Publishing. (Arabic)
- Fraser v. Evans [1969] 1 All E.R. 8 (U.K.).

- Gharavi Esfahani, MH (1418). Hashie AlMakaseb. Vol 5, Qum: Mohaghegh Publishing. (Arabic)

- Ghasem Zadeh, SM (1383). Principle of Contracts and Obligations. Tehran: Dadgostar Publishing. (Persian)

- Hakim, SM (1400). Nahj Al-feghaha. Qum: 22 Bahman Publishing. (Arabic)

- Hekmat Nia, M (1387). Basis of Intellectual Property. $2^{\text {nd }}$ ed. Tehran: Fegh va Anishe Publishing. (Persian)

- House of Spring Gardens Ltd. v. Point Blank Ltd., [1983] F.S.R. 213, 253 (Ir.)

- Ibn Asir, M (1367). Al-Nahaye. Vol 4, Qum: Esmailian Publishing. (Arabic)

- Ibn Manzur, M (N.D). Lesan Al-Arab. Qum: Adab Publishing. (Arabic)

- Jafari Langroudi, MJ (1378). Law Terminology. $4^{\text {th }}$ ed. Tehran: Ganje Danesh Publishing. (Persian)

- Jafari Langroudi, MJ (1386). Al-Fareq. Vol 4, Tehran: Ganje Danesh Publishing. (Persian)

- Katouzian, N (1373). Special Contracts. $5^{\text {th }}$ ed. Tehran: Enteshar Publishing. (Persian)

- Katouzian, N (1376). Properties and Ownership. Tehran: Dadgostar Publishing. (Persian)

- Khansari, SA (1364). Jame Al-Madarek. Vol 3, $2^{\text {nd }}$ ed. Qum: Esmailian Publishing. (Arabic)

- Khomeini, SR (1413). Ketab Al-Beie. Vol 1, Tehran: Imam Khomeini Publishing. (Arabic)

- Khoui, SA (1412). Mesbah Al-Feghaha. Vol 2, Qum: Al-Montakhab Publishing. (Arabic) 
- Matarese v. Moore McCornack Lines, Inc., 71 USPQ 311 (2e Cir. 1946).

- Mohaghagh Karaki, A (1414). Jame AlMaghased. Vol 4, $2^{\text {nd }}$ ed. Al-Albeit Publishing. (Arabic)

- Montazeri, H (1415). Derasat Fi Al-Makaseb. Vol 2, Qum: Al-Fekr Publishing. (Arabic)

- Moravej Jazaieri, SMJ (1416). Hashie Orve. Vol 1, Qum : Al-Keteb Publishing. (Arabic)

- Mortazavi Langroudi, MM (N.D.). Abd AlSaheb. Vol 1, Qum: Al-Mofid. (Arabic)

- Naeeni, MM (1373). Havashi Ala Orve. Vol 1, Tehan: Mohamadi Publishing. (Arabic)

- Naraghi, A (1415). Mostanad Al-Shia. Vol 14, Qum: Al-Albeit Publishing. (Arabic)

- Osborn v. Boeing Airplane Co., 135 USPQ 145 (9e Cir. 1962).

- Régis, F (1976). Le Knowhow: Sa Réservation en Droit Commun. France: NP.
- Risch, M (2007). "Why Do We Have Trade Secrets?". MARQ. INTELL . PROP. L. REV, 11(1): 45-65.

- Rouhani, SMS (1389). Fegh Al-Sadegh. Vol 14, $5^{\text {th }}$ ed. Qum: Shorough Publishing. (Arabic)

- Sarbazian, M (1389). International Contracts of "Knowhow". PhD thesis under supervision of Dr. Shiravi, Qum: University of Tehran (Farabi). (Persian)

- Shahidi, M (1377). Formation of Contracts and Obligations. Tehran: Hoghoghdan Publishing. (Persian)

- Shahidi, M (1385). Civil Law 6. $5^{\text {th }}$ ed. Tehran: Majd Publishing. (Persian)

- Shobair, MO (1418). Al-Moamelat Al-Mali. Jordan: Al-Nafaes Publishing. (Arabic)

- Yazdi, SMK (1410). Hashie Al-Makaseb. Vol 1, Qum: Esmailian Publishing. (Arabic) 